\title{
Evolution of dissolved and particulate chromophoric materials during the VAHINE mesocosm experiment in the New Caledonian coral lagoon (south-west Pacific)
}

\author{
Marc Tedetti ${ }^{1}$, Lauriane Marie ${ }^{1, a}$, Rüdiger Röttgers ${ }^{2}$, Martine Rodier ${ }^{3}$, France Van Wambeke ${ }^{1}$, Sandra Helias ${ }^{1}$, \\ Mathieu Caffin ${ }^{1}$, Véronique Cornet-Barthaux ${ }^{1}$, and Cécile Dupouy ${ }^{1,4}$ \\ ${ }^{1}$ Aix Marseille Université, CNRS/INSU, Université de Toulon, IRD, Mediterranean Institute of Oceanography (MIO) UM \\ 110, 13288, Marseille, France \\ ${ }^{2}$ Helmholtz-Zentrum Geesthacht, Centre for Materials and Coastal Research, Institute for Coastal Research, Remote Sensing, \\ Geesthacht, Germany \\ ${ }^{3}$ IRD, Université de la Polynésie française, Institut Louis Malardé, Ifremer, UMR 241, Ecosystèmes Insulaires Océaniens \\ (EIO), IRD Tahiti, PB 529, 98713 Papeete, Tahiti, French Polynesia \\ ${ }^{4}$ Institut de Recherche pour le Développement, AMU/CNRS/INSU, Université de Toulon, Mediterranean Institute of \\ Oceanography (MIO) UM110, 98848 Noumea, New Caledonia \\ ${ }^{a}$ present address: Université de Bretagne Occidentale, LEMAR, UMR-CNRS 6539, Groupe Chimie Marine, Place N. \\ Copernic, 29280 Plouzané, France
}

Correspondence to: Marc Tedetti (marc.tedetti@mio.osupytheas.fr)

Received: 13 October 2015 - Published in Biogeosciences Discuss.: 29 October 2015

Revised: 6 May 2016 - Accepted: 18 May 2016 - Published: 3 June 2016

\begin{abstract}
In the framework of the VAHINE project, we investigated the spectral characteristics and the variability of dissolved and particulate chromophoric materials throughout a 23-day mesocosm experiment conducted in the south-west Pacific at the mouth of the New Caledonian coral lagoon $\left(22^{\circ} 29.073 \mathrm{~S}-166^{\circ} 26.905 \mathrm{E}\right)$ from 13 January to 4 February 2013. Samples were collected in a mesocosm fertilized with phosphate at depths of 1,6 and $12 \mathrm{~m}$ and in the surrounding waters. Light absorption coefficients of chromophoric dissolved organic matter (CDOM) $\left[a_{\mathrm{g}}(\lambda)\right]$ and particulate matter $\left[a_{\mathrm{p}}(\lambda)\right]$ were determined using a point-source integrating-cavity absorption meter (PSICAM), while fluorescent DOM (FDOM) components were determined from excitation-emission matrices (EEMs) combined with parallel factor analysis (PARAFAC). The evolutions of $a_{\mathrm{g}}(\lambda)$ and $a_{\mathrm{p}}(\lambda)$ in the mesocosm were similar to those of total chlorophyll $a$ concentration, Synechococcus spp. and picoeukaryote abundances, bacterial production, particulate organic nitrogen and total organic carbon concentrations, with roughly a decrease from the beginning of the experiment to days 910 , and an increase from days $9-10$ to the end of the experi-
\end{abstract}

ment. In the surrounding waters, the same trend was observed but the increase was much less pronounced, emphasizing the effect of the phosphate fertilization on the mesocosm's plankton community. Correlations suggested that both Synechococcus cyanobacteria and heterotrophic bacteria were strongly involved in the production of CDOM and absorption of particulate matter. The increase in phytoplankton biomass during the second part of the experiment led to a higher contribution of particulate material in the absorption budget at $442 \mathrm{~nm}$. The three FDOM components identified (tryptophan-, tyrosine- and ultraviolet C (UVC) humic-like fluorophores) did not follow the evolution of CDOM and particulate matter, suggesting they were driven by different production/degradation processes. Finally, the results of this work support the idea there is indirect coupling between the dynamics of $\mathrm{N}_{2}$ fixation and that of chromophoric material via the stimulation of Synechococcus bloom. 


\section{Introduction}

Besides water itself, light absorption in the marine environment is due to three main biogeochemical constituents: (1) chromophoric dissolved organic matter (CDOM), also known as gelbstoff, gilvin and yellow substances, and chromophoric particulate matter, subdivided into (2) phytoplankton (photoautotrophic microorganisms), composed of both prokaryotic (cyanobacteria) and eukaryotic species (diatoms, dinoflagellates, coccolithophores, ...), and (3) non algal particles (NAP), comprising organic and minerogenic detritus, and heterotrophic organisms. Absorption spectra of CDOM, phytoplankton and NAP have been extensively studied over the last two decades in various oceanic provinces including coastal waters and open ocean (Blough and Del Vecchio, 2002; Babin et al., 2003; Bricaud et al., 2010; Matsuoka et al., 2014). Indeed, in addition to their key role in the oceanic carbon cycle, these three constituents strongly influence the underwater light field and the apparent optical properties of seawater. The knowledge of their absorption spectra is thus essential for bio-optical modelling and remote sensing applications but can also be used to investigate biological processes in the ocean.

Absorption coefficients of CDOM $\left[a_{\mathrm{g}}(\lambda)\right]$ and NAP $\left[a_{\text {nap }}(\lambda)\right]$ typically decrease monotonically (exponentially) from ultraviolet (UV, $280-400 \mathrm{~nm})$ to visible $(400-700 \mathrm{~nm})$ wavelengths (Nelson et al., 1998; Swan et al., 2009; Tilstone et al., 2012). Even though CDOM absorption spectra are usually featureless, some "shoulders" have been observed sporadically in the UV and visible spectral domains and attributed to the presence of dissolved absorbing pigments released by phytoplankton cells: mycosporine-like amino acids (MAAs) at $310-320$ or at $330-360 \mathrm{~nm}$, and phaeopigments or non-chlorin metal-free porphyrins at $410-420 \mathrm{~nm}$ (Whitehead and Vernet, 2000; Röttgers and Koch, 2012; Organelli et al., 2014; Pavlov et al., 2014). In contrast, absorption coefficients of phytoplankton $\left[a_{\phi}(\lambda)\right]$ determined from natural samples commonly display two main peaks in the visible range, around $435-450$ and $675 \mathrm{~nm}$, attributable to its content in total chlorophyll $a$ (TChl $a=$ mono Chl $a+\operatorname{divinyl~Chl~} a$ ) (Lutz et al., 1996; Dupouy et al., 1997; Bricaud et al., 2004), but may also reveal other peaks or shoulders resulting from the presence of other pigments: MAAs at $325 \mathrm{~nm}$ (Bricaud et al., 2010), TChl $b$, TChl $c$ and photoprotective carotenoids at $460-470 \mathrm{~nm}$, photosynthetic carotenoids and photoprotective keto-carotenoids at $490 \mathrm{~nm}$ (Carreto, 1985; Stuart et al., 1998; Wozniak et al., 1999; Lohrenz et al., 2003) as well as phycoerythrin at $550 \mathrm{~nm}$ (Morel, 1997). Hence, while chromophoric detrital matter $(\mathrm{CDM}=\mathrm{CDOM}+\mathrm{NAP})$ is the major contributor to total absorption in the UV domain $(\sim 60$ $95 \%)$, in the blue region ( $440-490 \mathrm{~nm})$, the contributions of $\mathrm{CDM}$ and phytoplankton tend to be equivalent $(\sim 40-50 \%)$, while CDOM alone is accounting for $\sim 80-95 \%$ of CDM in the UV and blue ranges (Siegel et al., 2002, 2005; Tedetti et al., 2010; Nelson and Siegel, 2013).
In "Case 1 waters" (Morel and Prieur, 1977), which are generally - but not necessarily - open ocean clear waters, optical properties are controlled by phytoplankton and all its derived material, and TChl $a$ concentration may be utilized as an index of optical properties thanks to its covariation with $a_{\phi}(\lambda), a_{\mathrm{g}}(\lambda), a_{\text {nap }}(\lambda)$ and particulate backscattering coefficient $\left[b_{\mathrm{bp}}(\lambda)\right]$ (Antoine et al., 2014). Due to the covariation with $a_{\phi}(\lambda)$ in Case 1 waters, CDOM is considered as being a by-product of phytoplanktonic production. Nonetheless, recent studies have highlighted some degree of de-phasing between the dynamics in phytoplankton and that of CDOM at the global, regional or seasonal scale (Siegel et al., 2002; Morel et al., 2010; Xing et al., 2014). Whilst photobleaching is now considered as a major degradation process of CDOM in surface waters (Del Vecchio and Blough, 2002; Helms et al., 2008; Bracchini et al., 2010; Swan et al., 2012), the main source of CDOM in open ocean is still a matter of debate, particularly for its "humic-like" component, which absorbs light over a broad range of UV and visible wavelengths and fluoresces in the visible domain (Andrew et al., 2013). Some works suggest that this humic-like CDOM is in part a remainder of terrestrial matter that has been diluted and transformed during transit to and within the ocean (Blough and Del Vecchio, 2002; Hernes and Benner, 2006; Murphy et al., 2008; Andrew et al., 2013). Conversely, other studies put forward its autochthonous marine source and its production from phytoplankton, including green algal, diatoms, dinoflagellates (Vernet and Whitehead, 1996; Romera-Castillo et al., 2010, 2011; Chari et al., 2013), the diazotrophic ( $\mathrm{N}_{2}$-fixing) cyanobacteria Trichodesmium spp. (Subramaniam et al., 1999; Steinberg et al., 2004) and the non-diazotrophic picocyanobacteria Synechococcus spp. and Prochlorococcus spp. (Romera-Castillo et al., 2011), from zooplankton (Steinberg et al., 2004; Ortega-Retuerta et al., 2009), or from the bacterial degradation (mineralization) of phytoplankton-derived organic matter (Nelson et al., 1998, 2010; Swan et al., 2009).

The New Caledonian coral lagoon, located in the southwest Pacific, is a tropical, oligotrophic low-nutrient lowchlorophyll (LNLC) ecosystem in which diazotrophs such as cyanobacteria Trichodesmium spp. (Dupouy et al., 1988, 2008; Masotti et al., 2007; Rodier and Le Borgne, 2010) and diazotrophic picocyanobacteria (Biegala and Raimbault, 2008) but also non-diazotrophic picocyanobacteria such as Synechococcus spp. and Prochlorococcus spp. (Biegala and Raimbault, 2008; Neveux et al., 2009) play a significant role. Although the biogeochemical conditions in the New Caledonian coral lagoon are well documented for several years (see review by Grenz et al., 2010), the dynamics of CDOM remains poorly known in this environment. In the framework of the VAHINE (VAriability of vertical and tropHIc transfer of fixed $\mathrm{N}_{2}$ in the south wEst Pacific) mesocosm experiment, the objectives of the present study were (1) to assess the spectral characteristics and the variability of dissolved and particulate chromophoric materials through- 
out a 23-day mesocosm experiment and (2) to tentatively identify the main biogeochemical contributors (diazotrophic and non-diazotrophic primary producers, heterotrophic bacteria) driving changes in chromophoric material over the course of the experiment. Chromophoric parameters we examined here were absorption coefficients of CDOM $\left[a_{\mathrm{g}}(\lambda)\right]$ and particulate matter $\left[a_{\mathrm{p}}(\lambda)=a_{\phi}(\lambda)+a_{\text {nap }}(\lambda)\right]$, determined over the spectral domain $370-720 \mathrm{~nm}$, the spectral slope of CDOM $\left(S_{\mathrm{g}}\right)$, computed over the range $370-500 \mathrm{~nm}$, as well as fluorescent DOM (FDOM) components, determined from excitation-emission matrices (EEMs) combined with parallel factor analysis (PARAFAC).

\section{Material and methods}

\subsection{The mesocosm experiment}

\subsubsection{Study site and mesocosm description}

The VAHINE mesocosm experiment was conducted from 13 January to 4 February 2013 in the south-west Pacific at a mouth of the New Caledonian coral lagoon, $28 \mathrm{~km}$ off the coast of New Caledonia $\left(22^{\circ} 29.073 \mathrm{~S}-166^{\circ} 26.905 \mathrm{E}\right)$ (Fig. 1). At the deployment site the water depth was $25 \mathrm{~m}$ and the bottom was sandy. The site was protected by land from the dominant trade winds (SE sector) and characterized by high influence of oceanic oligotrophic waters coming from outside the lagoon through the Boulari passage (Ouillon et al., 2010). Three large mesocosms (hereafter called M1, M2 and M3), of $50 \mathrm{~m}^{3}$ volume each, were deployed (Fig. 2). All details concerning the mesocosm design and deployment are given in Bonnet et al. (2016). In brief, the mesocosms consisted in large cylindrical bags made of one polyethylene film and one ethylene vinyl acetate (EVA, 19\%) film, each $500 \mu \mathrm{m}$ thick, with nylon meshing in between to allow maximum resistance and light penetration. They were $2.3 \mathrm{~m}$ in diameter, $15 \mathrm{~m}$ in depth and were equipped with removable sediment traps, allowing collection of sinking material. The top of the bags were maintained $1 \mathrm{~m}$ above the surface with floats to prevent inflow of external water. Their straightness was maintained by weights at the bottom of the mesocosms. Before starting sampling, the mesocosms were left opened from the bottom for $24 \mathrm{~h}$ to insure a total homogeneity of the water column.

\subsubsection{Nutrient fertilization}

To prevent phosphate limitation, the mesocosms were fertilized in the evening of day 4 with dissolved inorganic phosphorus (DIP) to a final concentration of $0.8 \mu \mathrm{M}$ (see details of the fertilization procedure in Bonnet et al., 2016). This phosphate fertilization aimed at stimulating the diazotroph activity.

\subsubsection{Sampling and in situ measurements}

During the 23 days of the experiment, seawater sampling was performed every morning from a $4 \mathrm{~m}^{2}$ floating platform at three depths (1, 6 and $12 \mathrm{~m})$ in each mesocosm and in the surrounding waters close to the mesocosms ("OUT") using a compressed air-driven, metal-free pump (AstiPure ${ }^{\mathrm{TM}}$ ) connected to a polyethylene tubing. Samples were filled into $50 \mathrm{~L}$ polypropylene carboys and immediately transported for subsampling and sample treatments onboard the R/V Alis, moored 1 nautical mile away from the mesocosm site. Along with discrete sampling, vertical profiles of temperature, salinity, Chl $a$ fluorescence, turbidity and light intensity were obtained daily (at 7 a.m. local time) in each mesocosm and in the surrounding waters using a 911plus conductivity temperature depth (CTD) profiler (Sea-Bird Electronics, Inc.). For our specific parameters, i.e. dissolved and particulate chromophoric materials, we only sampled the mesocosm M1 at 1,6 and $12 \mathrm{~m}$ depth and the surrounding waters at $1 \mathrm{~m}$ depth.

\subsubsection{Filtration}

Onboard R/V Alis, samples for CDOM absorption and fluorescence measurements were immediately filtered under low vacuum $(<50 \mathrm{~mm} \mathrm{Hg})$ through $0.2 \mu \mathrm{m}$ polycarbonate filters ( $25 \mathrm{~mm}$ diameter, Nuclepore) using small, pre-combusted $\left(450^{\circ} \mathrm{C}, 6 \mathrm{~h}\right)$ glass filtration systems. Prior to sample filtration, the Nuclepore filters were cleaned by first soaking them for several minutes in $1 \mathrm{M} \mathrm{HCl}$, then in ultrapure water, and processing them by filtering through and discarding $300 \mathrm{~mL}$ of ultrapure water and lastly $50 \mathrm{~mL}$ of the sample. Then, $1 \mathrm{~L}$ of the sample was filtered and the $0.2 \mu \mathrm{m}$ filtrate transferred into pre-combusted Schott ${ }^{\circledR}$ glass bottles for analyses. Powder-free disposable gloves were worn during sampling, filtration and analyses to avoid sample contamination. All absorption coefficient measurements $\left[a_{\mathrm{g}}(\lambda)\right.$ and $\left.a_{\mathrm{g}+\mathrm{p}}(\lambda)\right]$ were performed directly onboard (see Sect. 2.2), while samples for fluorescence measurements were stored at $4{ }^{\circ} \mathrm{C}$ in the dark for several days until analyses.

\subsubsection{The two phases of the experiment}

In the results presented below, the 23-day mesocosm experiment was separated into two periods: P1, from day 5 to day 14 , and P2, from day 15 to day 23 . P1 and P2 denote the two phases of the experiment when the diazotrophic community was dominated by diatom-diazotroph associations (DDAs), more specifically heterocyst-forming Richelia associated with Rhizosolenia and unicellular cyanobacteria group C (UCYN-C), respectively (Berthelot et al., 2015; Turk-Kubo et al., 2015). 


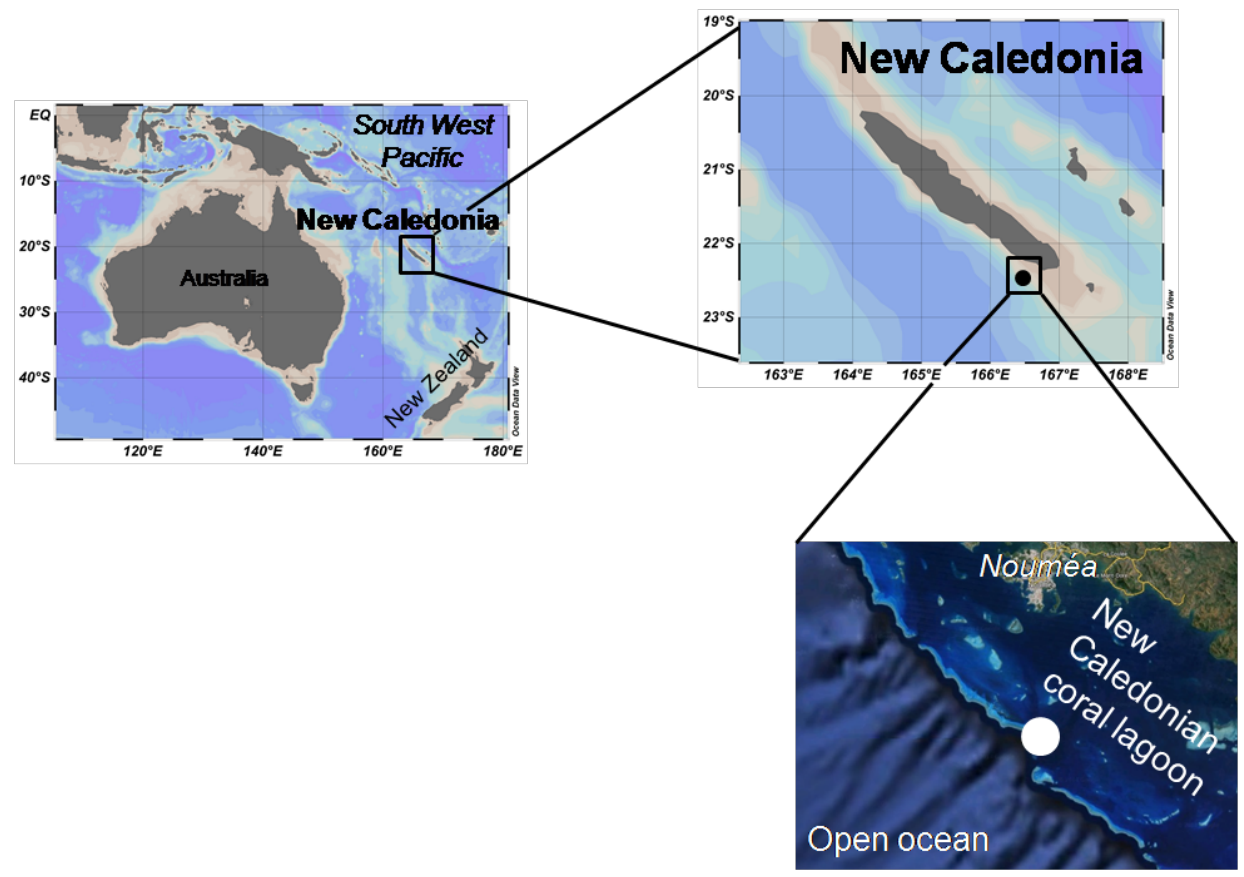

Figure 1. Location of the site of the VAHINE mesocosm experiment at the mouth of the New Caledonian coral lagoon, $28 \mathrm{~km}$ off the coast of New Caledonia, in the south-west Pacific (Ocean Data View software version 4.6.5, Schlitzer, R., http://odv.awi.de, 2014, and Google Earth).

\subsection{Absorption of CDOM and particulate matter}

\subsubsection{Measurement}

Absorption coefficients of CDOM and CDOM + particulate matter $\left[a_{\mathrm{g}}(\lambda)\right.$ and $\left.a_{\mathrm{g}+\mathrm{p}}(\lambda)\right]$ were determined by measuring absorption of $0.2 \mu \mathrm{m}$ filtered and unfiltered samples using a point-source integrating-cavity absorption meter (PSICAM) instrument as described by Röttgers et al. (2007) and Röttgers and Doerffer (2007). The cavity of the PSICAM was filled with purified water (Milli-Q water), air bubbles were removed from the cavity wall and the central light sphere by gentle shaking, and a reference intensity spectrum was recorded between 370 and $726 \mathrm{~nm}$. Afterwards, sample water was poured into the cavity in the same way, and a sample intensity spectrum was recorded. The cavity was rinsed and filled with purified water again, and a second reference intensity spectrum was recorded. The two reference spectra were used to calculate two "transmissions" (sample/reference) and, further, two absorption coefficient spectra. The mean of these two spectra was taken as the real absorption coefficient spectrum. The calibration of the PSICAM consisted of determinations of the total cavity reflectivity spectrum by using solutions of the dye nigrosine (Certistain ${ }^{\circledR}$, Merck) with maximum absorption between 1 and $3 \mathrm{~m}^{-1}$. Absorption spectra were corrected for salinity and temperature differences between sample and reference water according to Röttgers and Doerffer (2007). The mean precision of the PSICAM within the range $370-700 \mathrm{~nm}$ is $\pm 0.0008 \mathrm{~m}^{-1}$, whereas its accuracy here is $\pm 2 \%$, even for absorption values $<0.1 \mathrm{~m}^{-1}$.

\subsubsection{Particulate absorption and CDOM spectral slope determination}

Absorption coefficients of particulate matter $\left[a_{\mathrm{p}}(\lambda)\right]$ were determined by subtracting $a_{\mathrm{g}}(\lambda)$ from $a_{\mathrm{g}+\mathrm{p}}(\lambda)$ over the range $370-720 \mathrm{~nm}$. Spectral slope of $a_{\mathrm{g}}(\lambda), S_{\mathrm{g}}\left(\right.$ in $\mathrm{nm}^{-1}$ ), was computed by applying a nonlinear (exponential), leastsquares fit to the $a_{\mathrm{g}}(\lambda)$ values between 370 and $500 \mathrm{~nm}$ in accordance with the following formula:

$a_{\mathrm{g}}(\lambda)=a_{\mathrm{g}}\left(\lambda_{0}\right) \times e^{-S_{\mathrm{g}}\left(\lambda-\lambda_{0}\right)}$.

The fit was conducted on raw (i.e. not log-transformed) data according to the recommendations by Twardowski et al. (2004). The average correlation coefficient $(r)$ of the exponential least-squares fits was $1.00(n=72)$. The spectral range used here for the slope determination $(370-500 \mathrm{~nm})$ was close to that employed in previous studies for different oceanic waters (i.e. 350-500 nm) (Babin et al., 2003; Röttgers and Doerffer, 2007; Bricaud et al., 2010; Para et al., 2010; Organelli et al., 2014). 

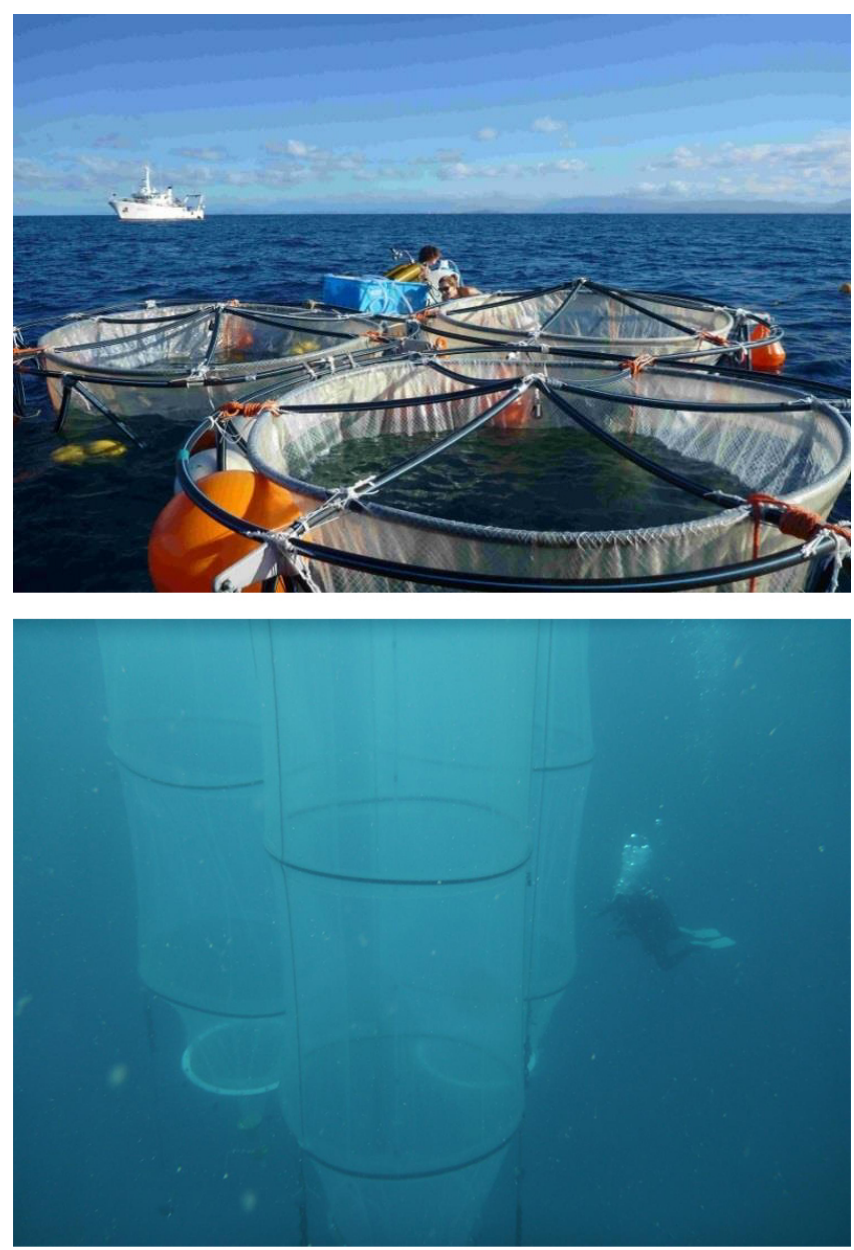

Figure 2. Pictures of the VAHINE mesocosms deployed at the mouth of the New Caledonian coral lagoon.

\subsection{Fluorescence of DOM}

\subsubsection{Measurements}

FDOM measurements were performed on $0.2 \mu \mathrm{m}$ filtered samples using a Hitachi F-7000 spectrofluorometer. The correction of spectra for instrumental response was conducted from 200 to $600 \mathrm{~nm}$ according to the procedure recommended by the manufacturer (Hitachi F-7000 Instruction Manual) and fully described in Tedetti et al. (2012). The excitation (Ex) and emission (Em) correction curves were applied internally by the instrument to correct each fluorescence measurement acquired in signal over reference ratio mode. The samples were allowed to reach room temperature in the dark and transferred into a $1 \mathrm{~cm}$ pathlength far-UV transparent silica quartz cuvette $(170-2600 \mathrm{~nm}$; LEADER LAB). The sample in the cuvette was kept at $20^{\circ} \mathrm{C}$ inside the instrument using a circulating water bath connected to the cell holder. The cuvette was cleaned with $1 \mathrm{M} \mathrm{HCl}$ and ultrapure water, and triple rinsed with the sample before use.
EEMs were generated over $\lambda_{\text {Ex }}$ between 200 and $500 \mathrm{~nm}$ in $5 \mathrm{~nm}$ intervals, and $\lambda_{\mathrm{Em}}$ between 280 and $550 \mathrm{~nm}$ in $2 \mathrm{~nm}$ intervals, with $5 \mathrm{~nm}$ slit widths on both Ex and Em sides, a scan speed of $1200 \mathrm{~nm} \mathrm{~min}^{-1}$, a time response of $0.5 \mathrm{~s}$ and a PMT voltage of $700 \mathrm{~V}$. Blanks (ultrapure water) and solutions of 0.1 to $10 \mu \mathrm{g} \mathrm{L}{ }^{-1}$ quinine sulphate dihydrate (Fluka, purum for fluorescence) in $0.05 \mathrm{M}$ sulphuric acid were run with each set of the samples. Two replicates were run for each sample.

\subsubsection{Fluorescence data processing}

Different processing steps were carried out on the fluorescence data: (1) all the fluorescence data were normalized to the intensity of the ultrapure water Raman scatter peak at $\lambda_{\mathrm{Ex}} / \lambda_{\mathrm{Em}}$ of $275 / 303 \mathrm{~nm}$, measured daily as an internal standard (Coble, 1996). This value varied by $4 \%$ $(n=20)$. (2) The mean, normalized EEM of ultrapure water was subtracted from normalized sample EEMs to eliminate the water Raman scatter signal. (3) These blank-corrected sample EEMs were converted into quinine sulphate unit (QSU), where 1 QSU corresponded to the fluorescence of $1 \mu \mathrm{g} \mathrm{L}^{-1}$ quinine sulphate at $\lambda_{\mathrm{Ex}} / \lambda_{\mathrm{Em}}$ of $350 / 450 \mathrm{~nm}(5 \mathrm{~nm}$ slit widths) (Coble, 1996; Murphy et al., 2008). The conversion in QSU was made by dividing each EEM fluorescence data by the mean slope of a linear regression of fluorescence vs. concentration for the different quinine sulphate solutions (i.e. 8.4 arbitrary fluorescence intensity units/QSU). $r$ values of these linear regressions were on average 0.99 and the detection and quantification limits of the fluorescence measurements were 0.19 and 0.63 QSU, respectively. The water Raman scatter peak was integrated from $\lambda_{\mathrm{Em}} 380$ to $426 \mathrm{~nm}$ at $\lambda_{E x}$ of $350 \mathrm{~nm}$ for ultrapure water samples. The mean value was used to establish a conversion factor between QSU and Raman unit $\left(\mathrm{RU}, \mathrm{nm}^{-1}\right)$, based on the Raman-area normalized slope of the quinine sulphate linear regression. The conversion factor was $0.025 \mathrm{RU}$ per QSU. Considering the low $a_{\mathrm{g}}(\lambda)$ values, samples were not corrected for inner filter effects (Stedmon and Bro, 2008).

\subsection{Parallel factor analysis (PARAFAC)}

In this work, a PARAFAC model was created and validated for 130 calibrated EEMs according to the method by Stedmon et al. (2003). The EEM wavelength ranges used were 210-500 and 280-550 nm for Ex and Em, respectively. EEMs were merged into a three-dimensional data array of the form: 130 samples $\times 59 \lambda_{\mathrm{Ex}} \times 136 \lambda_{\mathrm{Em}}$. The PARAFAC program was executed using the DOMFluor toolbox v1.6 (Stedmon and Bro, 2008) running under MATLAB ${ }^{\circledR} 7.10 .0$ (R2010a). The full analysis showed that no outliers were present in the data set. The validation of the PARAFAC model (running with the non-negativity constraint) and the determination of the correct number of components (from 2 to 6 components tested) were achieved through the examination of (1) the percentage of explained 
variance, (2) the shape of residuals, (3) the split half analysis and (4) the random initialization using the Tucker Congruence Coefficients (Tedetti et al., 2012). The fluorescence intensities of each component found are given in QSU. The fluorescence intensities in QSU provided for each sample is the mean of the two replicates with a coefficient of variance $(\mathrm{CV})<10 \%$.

\subsection{Biogeochemical and biological analyses}

Filters for the determination of the TChl $a$ concentration were collected by filtering $550 \mathrm{~mL}$ of sample water onto a GF/F filter (Whatman). The filters were directly shock-frozen and stored in liquid $\mathrm{N}_{2}$. TChl $a$ was extracted in methanol and measured by fluorometry (Le Bouteiller et al., 1992). The precision of the measurement was $\pm 0.005 \mu \mathrm{g} \mathrm{L}^{-1}$.

For the determination of phycoerythrin concentration, water samples $(3-4 \mathrm{~L})$ were filtered onto $0.4 \mu \mathrm{m}$ Nuclepore polycarbonate filters and immediately frozen in liquid $\mathrm{N}_{2}$ until analysis. Phycoerythrin was extracted in a $4 \mathrm{~mL}$ glycerolphosphate mixture (50/50) according to Neveux et al. (2009) after vigorous shaking for resuspension of particles (Wyman, 1992), and then quantified by fluorometry using a Perkin Elmer LS55 spectrofluorometer $\left(\lambda_{\mathrm{Ex}}: 450-580 \mathrm{~nm}\right.$ at $\lambda_{\mathrm{Em}}$ of $605 \mathrm{~nm}$ ) (Lantoine and Neveux, 1997). The measurement precision was $\sim 16 \%$.

Pico- and nano-phytoplankton abundances were analysed by flow cytometry. Samples $(1.8 \mathrm{~mL})$ were collected from the mesocosm everyday from 1,6 and $12 \mathrm{~m}$ depth in cryotubes, fixed with $200 \mu \mathrm{L}$ of paraformaldehyde (4\% final concentration), left $15 \mathrm{~min}$ at ambient temperature, flash frozen in liquid $\mathrm{N}_{2}$ and stored at $-80^{\circ} \mathrm{C}$ until analysis on a FACSCalibur (BD Biosciences) flow cytometer as described in Marie et al. (1999). Before analysis, samples were thawed at ambient temperature in the dark. $600 \mu \mathrm{L}$ of each sample were mixed and homogenized with $25 \mu \mathrm{L}$ of TrueCount beads and $10 \mu \mathrm{L}$ of $2 \mu \mathrm{m}$ diameter beads (Fluoresbryte ${ }^{\mathrm{TM}}$, Polysciences) used as a reference for size discrimination between pico- and nano-phytoplankton. Phytoplankton communities were clustered as Prochlorococcus spp. cell-like, Synechococcus spp. cell-like, nanoeukaryotes-cell-like and picoeukaryotes-celllike according to their optical properties (light-scattered and fluorescence emission by the cells) (Marie et al., 1999).

For the determination of microphytoplankton community composition (diatoms), water samples $(250 \mathrm{~mL})$ were taken every day by pumping and preserved with formalin. In the laboratory, samples were sedimented and microphytoplankton species were identified and enumerated under-inverted microscope.

Bacterial production (BP) was estimated using the ${ }^{3} \mathrm{H}-$ leucine incorporation technique (Kirchman et al., 1985), adapted to the centrifugation method (Smith and Azam, 1992). Radioactivity was counted using a Liquid Scintillation Analyzer Packard 2100 TR and the ${ }^{3} \mathrm{H}$ counting effi- ciency was corrected for quenching. BP was calculated from leucine incorporation rates using the conversion factor of $1.5 \mathrm{~kg} \mathrm{C} \mathrm{mol}^{-1}$ leucine, and is shown here in $\mathrm{ng} \mathrm{C} \mathrm{L}^{-1} \mathrm{~h}^{-1}$.

Samples for total organic carbon (TOC) concentrations were collected in duplicate in precombusted $\left(4 \mathrm{~h}, 450{ }^{\circ} \mathrm{C}\right)$, $12 \mathrm{~mL}$ sealed glassware flask, acidified with orthophosphoric acid and stored in dark at $4{ }^{\circ} \mathrm{C}$ until analysis. Samples were analysed by using a TOC-5000 total carbon analyser (Sohrin and Sempéré, 2005). The average TOC concentrations in the Deep Atlantic Water and low carbon water reference standards were $45 \pm 2 \mu \mathrm{MC}, n=24$ and $1 \pm 0.3 \mu \mathrm{MC}, n=24$, respectively. The analytical precision of the procedure was $\leq 2 \%$.

Dissolved organic nitrogen (DON) concentrations were calculated from total nitrogen (TN) concentrations subtracted by particulate organic nitrogen (PON) and dissolved inorganic nitrogen (DIN) concentrations. Samples were collected in $50 \mathrm{~mL}$ glass bottles and stored at $-20^{\circ} \mathrm{C}$ until analysis. The samples were divided in two parts after a rapid thaw for analysis of both organic and inorganic concentrations. TN concentration was determined according to the wet oxidation procedure described in Pujo-Pay and Raimbault (1994). Samples for PON concentrations were collected by filtering $1 \mathrm{~L}$ of water on GF/F filters and analysed according to the wet oxidation protocol (Pujo-Pay and Raimbault, 1994) with a precision of $0.06 \mu \mathrm{M}$. DIN concentration was determined according to Aminot and Kérouel (2007). Measurements were conducted using a segmented flow auto-analyser (AutoAnalyzer AA3 HR, SEAL Analytical).

\subsection{Statistics}

Linear regression analyses and one-way analyses of variance (ANOVA) were performed with StatView 5.0 and the statistics package provided in Microsoft Excel 11.0. ANOVA was used to compare the means of independent data groups (normally distributed). For the different analyses and tests, the significance threshold was set at $p<0.05$.

\section{Results}

\subsection{Evolution of the core parameters in the mesocosm}

The detailed description of temperature, salinity and nutrient concentrations in the three mesocosms is provided in Bonnet et al. (2016). Briefly, water temperature progressively increased inside and outside the mesocosms from 25.4 to $26.2{ }^{\circ} \mathrm{C}$ over the course of the 23 -day experiment. Salinity also progressively increased from 35.1 to 35.5 but this increase was less pronounced in the surrounding waters with salinities of 35.4 at day 23. Temperature and salinity were homogeneous over depth in the mesocosms, the water column having been well mixed throughout the experiment. In the mesocosms, average concentrations of $\mathrm{NO}_{3}^{-}+\mathrm{NO}_{2}^{-}$were $<0.04 \mu \mathrm{M}$ before the DIP fertilization (day 4) and decreased 
to $0.01 \mu \mathrm{M}$ at the end of the experiment. In contrast, $\mathrm{NH}_{4}^{+}$ concentrations were $\sim 0.01 \mu \mathrm{M}$ up to day 18 , and then increased up to $0.06 \mu \mathrm{M}$ at day 23. DIP concentrations increased from $0.02-0.05 \mu \mathrm{M}$ before the fertilization to $0.8 \mu \mathrm{M}$ just after, and decreased gradually over time to return to their initial concentrations at day $23(0.02-0.08 \mu \mathrm{M})$. In the surrounding waters, $\mathrm{NO}_{3}^{-}$remained $<0.20 \mu \mathrm{M}$ and DIP was $0.05 \mu \mathrm{M}$ all over the experiment (Berthelot et al., 2015; Bonnet et al., 2016).

For all the parameters described below, including CDOM and FDOM data, no significant difference was found with depth, except for TChl $a$ and PON whose concentrations were higher at $12 \mathrm{~m}$ depth than at 1 and $6 \mathrm{~m}$ depths (ANOVA, $n=20-22, p=0.003-0.04)$. Therefore, in the following paragraphs, the parameter descriptors are generally given in term of depth-averaged values.

\subsection{Evolution of phytoplankton biomass, bacterial production and organic $\mathrm{N}$ and $\mathrm{C}$ pools in the mesocosm}

TChl $a$, PON concentrations and BP in the mesocosm M1 and in the surrounding waters (OUT) generally increased throughout the experiment, with a decrease from day 4 to day 9 and then an increase from day 9 to the end of the experiment (Fig. 3a, d, f). This increase was more pronounced in $\mathrm{M} 1$, where TChl $a$, PON concentrations and BP varying from 0.12 to $0.55 \mu \mathrm{g} \mathrm{L}^{-1}, 0.65$ to $1.31 \mu \mathrm{M}$ and 85 to $681 \mathrm{ng} \mathrm{C} \mathrm{L}^{-1} \mathrm{~h}^{-1}$, respectively. TChl $a$, PON concentrations and BP were significantly higher inside M1 during P2 (day 15 to day 23) than inside M1 during P1 (day 5 to day 14), and than outside during P1 and P2 (ANOVA, $n=25-30$, $p<0.0001-0.004)$ (Table 1). Phycoerythrin concentration decreased from day $4\left(0.36 \mu \mathrm{g} \mathrm{L}^{-1}\right)$ to day $9\left(0.05 \mu \mathrm{g} \mathrm{L}^{-1}\right)$, increased towards day $16\left(0.34 \mu \mathrm{g} \mathrm{L}^{-1}\right)$ and then oscillated to return to the value of $0.34 \mu \mathrm{g} \mathrm{L}^{-1}$ at day 23 (Fig. 3b). In contrast, in OUT, phycoerythrin concentration increased from day 9 to the end of the experiment, showing a strong raise at day $21\left(0.85 \mu \mathrm{g} \mathrm{L}^{-1}\right)$. Thus, during $\mathrm{P} 2$, phycoerythrin concentration was significantly higher outside M1 than inside (ANOVA, $n=9, p=0.004$ ) (Table 1). The TOC concentration decreased from day $4(70 \mu \mathrm{M})$ to day $11(64 \mu \mathrm{M})$ and increased from day 11 to day $22(81 \mu \mathrm{M})$ (Fig. 3c). This increase in the second part of the experiment was not observed in OUT. Although the TOC concentration was significantly higher during $\mathrm{P} 2$ than during $\mathrm{P} 1$ in M1 (ANOVA, $n=9$, $p=0.03$ ), there was no difference between M1 and OUT during P2 (ANOVA, $n=7-9, p=0.2$ ) (Table 1). The DON concentration was rather constant and only tended to decrease during P2 (Fig. 3e). No significant difference in DON concentrations was found between M1 and OUT (ANOVA, $n=22-29, p=0.07-0.7$ ) (Table 1).

The abundance of diazotrophs DDAs inside M1 increased from day $3\left(77 \times 10^{3}\right.$ nifH copies $\left.\mathrm{L}^{-1}\right)$ to day $9\left(190 \times 10^{3}\right.$ nifH copies $\left.\mathrm{L}^{-1}\right)$, decreased from day 9 to day $15\left(5.4 \times 10^{3}\right.$ nif $H$ copies $\left.\mathrm{L}^{-1}\right)$ and finally increased from day 15 to day $23\left(78 \times 10^{3}\right.$ nifH copies $\left.\mathrm{L}^{-1}\right)$. In OUT a quite similar pattern was observed despite a high value of $450 \times 10^{3}$ nifH copies $\mathrm{L}^{-1}$ at day 18 (Fig. 4a). No significant difference in the abundance of DDAs was observed in M1 between P1 and P2, and between M1 and OUT (ANOVA, $n=3-6, p=0.05-0.8$ ) (Table 1). On the other hand, the abundance of diazotrophic Group UCYN-C strongly increased from day $9\left(0.54 \times 10^{3}\right.$ nifH copies $\left.\mathrm{L}^{-1}\right)$ to day $23\left(110 \times 10^{3}\right.$ nifH copies $\left.\mathrm{L}^{-1}\right)$ in $\mathrm{M} 1$, while it increased much more slowly in OUT from day $10\left(0.32 \times 10^{3}\right.$ nifH copies $\left.\mathrm{L}^{-1}\right)$ to day 22 $\left(4.8 \times 10^{3}\right.$ nifH copies $\left.\mathrm{L}^{-1}\right)$ (Fig. 4b). Hence, the abundance of UCYN-C was much higher in M1 during P2 than in M1 during P1 (14 times higher) and than in OUT during P1 and P2 (22-53 times higher) (ANOVA, $n=3-6, p<0.0001$ ) (Table 1). It should be noticed that the abundances of DDAs and UCYN-C are reported as nifH (gene) copies $\mathrm{L}^{-1}$ rather than cells $\mathrm{L}^{-1}$ because there is currently little information about the number of nifH copies per genome in these diazotroph targets (Turk-Kubo et al., 2015). Total diatoms in M1 decreased from day 2 $\left(47 \times 10^{3}\right.$ cell $\left.\mathrm{L}^{-1}\right)$ to day $9\left(6 \times 10^{3}\right.$ cell $\left.\mathrm{L}^{-1}\right)$ and then

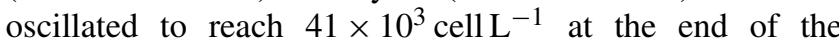
experiment, with a maximum value of $120 \times 10^{3}$ cell $\mathrm{L}^{-1}$ at day 15 (Fig. 4c). This was essentially due to the large diatom Cylindrotheca closterium (data not shown). No difference in abundance of total diatoms was observed between P1 and P2 (ANOVA, $n=5, p=0.2$ ). The abundances of Synechococcus spp., Prochlorococcus spp., picoeukaryotes and nanoeukaryotes decreased from day $4(\sim 43,16,2.2$ and $0.9 \times 10^{3}$ cell $\mathrm{mL}^{-1}$, respectively) to day $9(\sim 18,5,0.8$ and $0.6 \times 10^{3}$ cell $\mathrm{mL}^{-1}$, respectively) (Fig. $4 \mathrm{~d}-\mathrm{g}$ ). From day 9 to the end of the experiment, the abundance of Synechococcus spp. and picoeukaryotes noticeably increased to reach $\sim 90$ and $3.4 \times 10^{3}$ cell $\mathrm{mL}^{-1}$ at day 23 respectively, whereas the increase in Prochlorococcus spp. and nanoeukaryotes was much less (to $\sim 20$ and $1.3 \times 10^{3}$ cell $\mathrm{mL}^{-1}$ at day 23 , respectively). The abundance of Synechococcus spp., picoeukaryotes and nanoeukaryotes was significantly higher in P2 than in P1 (ANOVA, $n=23-24, p<0.0001-0.002$ ), while that of Prochlorococcus spp. was not different (ANOVA, $n=23-24, p=0.07$ ) (Table 1).

\subsection{Absorption spectra of CDOM and particulate matter}

CDOM absorption spectra of samples collected in M1 and OUT were quite similar, displaying an exponential decrease in $a_{\mathrm{g}}(\lambda)$ without any significant shoulder (Fig. 5). $a_{\mathrm{p}}(\lambda) \mathrm{spec}-$ tra, which reflect the absorption by both phytoplankton and NAP, were characterized by two main $\mathrm{Chl} a$ peaks, one between 432 and $442 \mathrm{~nm}$ (at $436 \mathrm{~nm}$ on average) and one between 672 and $682 \mathrm{~nm}$ (at $676 \mathrm{~nm}$ on average), while several shoulders also emerged at 376, 416, 464, 490 and $550 \mathrm{~nm}$ 

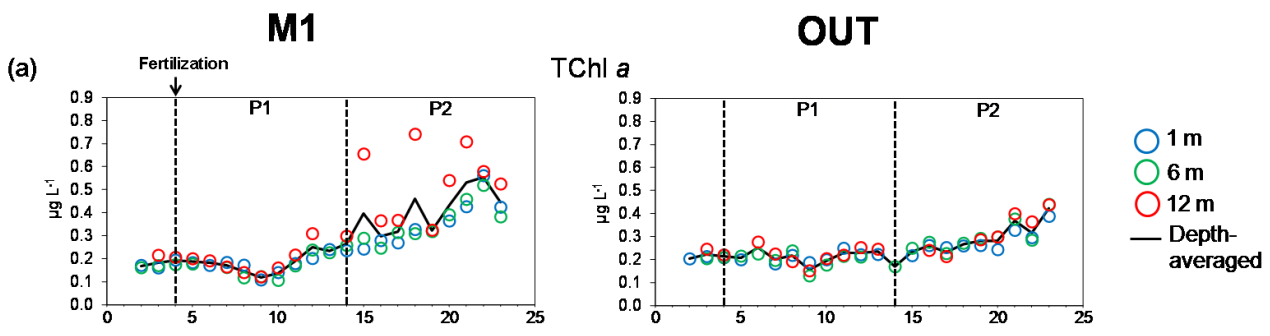

(b)

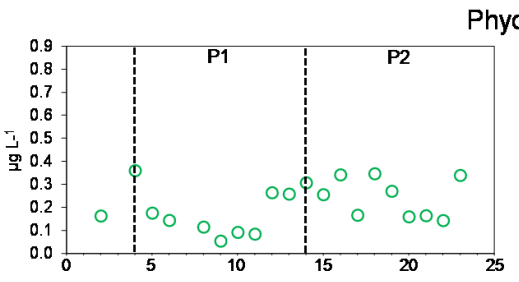

hycoerythrin

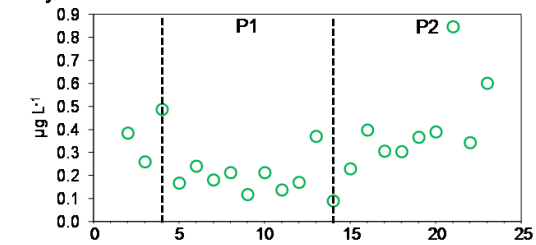

(c)

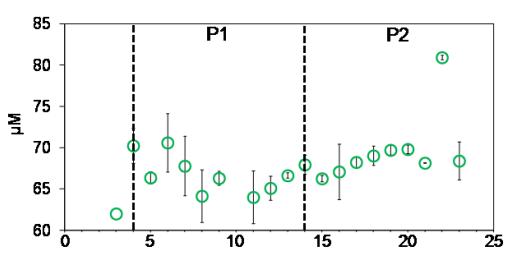

TOC

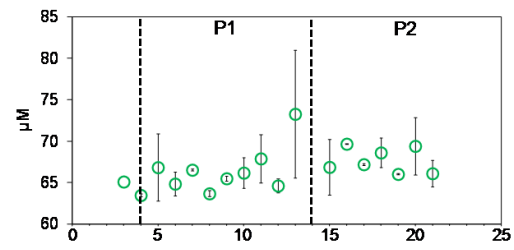

(d)

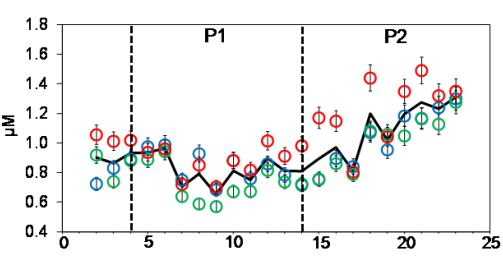

PON

(e)
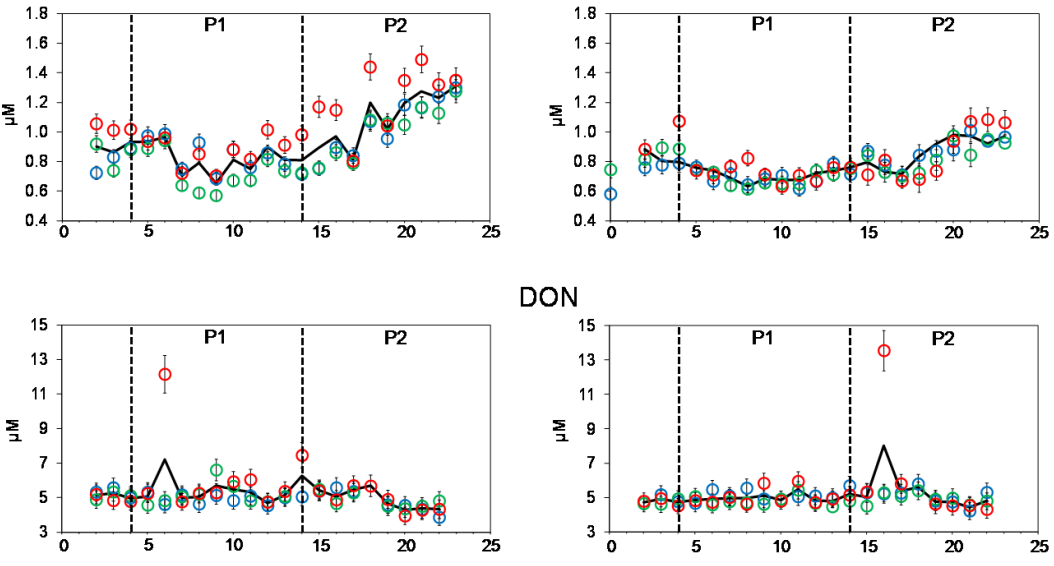

DON

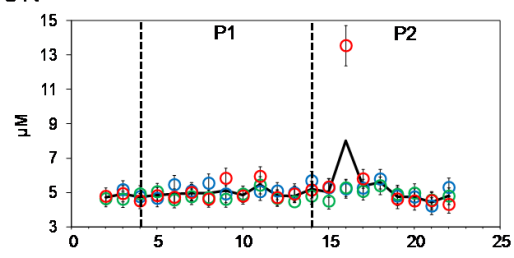

(f)

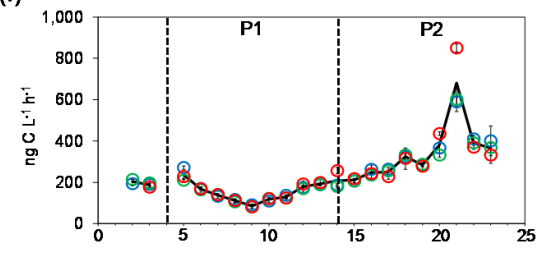

BP

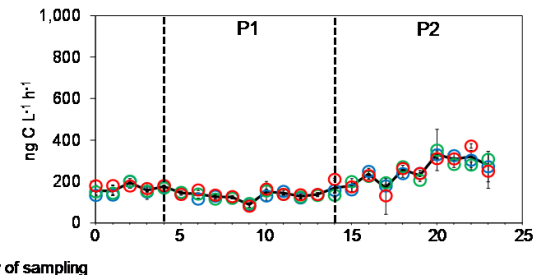

Figure 3. Evolution of (a) total chlorophyll $a$ (TChl $a$ ) and (b) phycoerythrin concentrations $\left(\mu g \mathrm{~L}^{-1}\right)$, (c) total organic carbon (TOC), (d) particulate organic nitrogen $(\mathrm{PON})$ and (e) dissolved organic nitrogen (DON) concentrations $(\mu \mathrm{M})$ and (f) bacterial production $(\mathrm{BP})$ (ng C L $\mathrm{C}^{-1} \mathrm{~h}^{-1}$ ) in the mesocosm M1 and in the surrounding waters (OUT) at 1, 6 and $12 \mathrm{~m}$ depths (except phycoerythrin and TOC concentrations, determined only at $6 \mathrm{~m}$ depth) over the course of the 23-day experiment. Dots are mean values with standard deviations from duplicate measurements, except for phycoerythrin. For TChl $a$, standard deviations are comprised within dots. Black line represents the depth-averaged values. P1: first part of the experiment, from day 5 to day 14; P2: second part of the experiment, from day 15 to day 23. 
M1

(a)

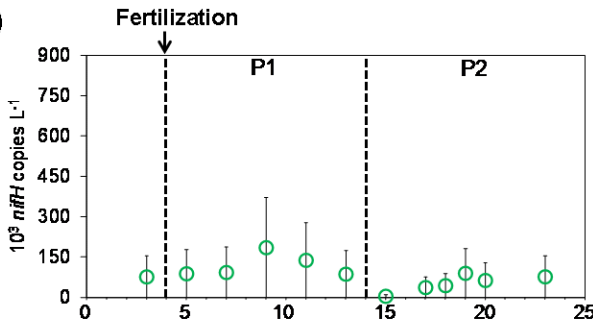

OUT

DDAs
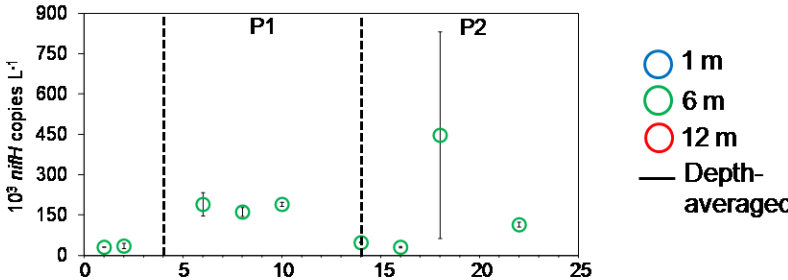

(b)

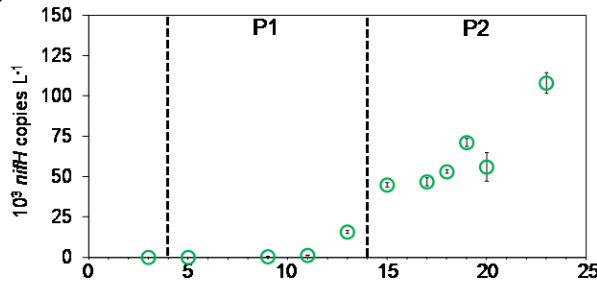

M1

(c)

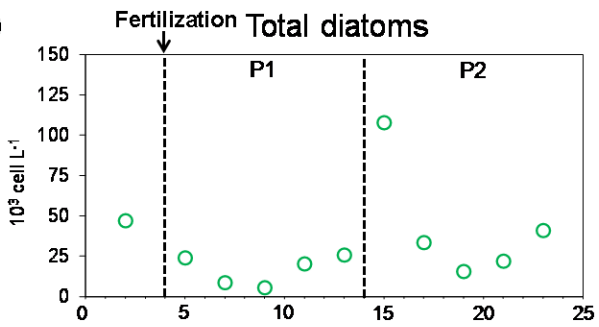

(e)

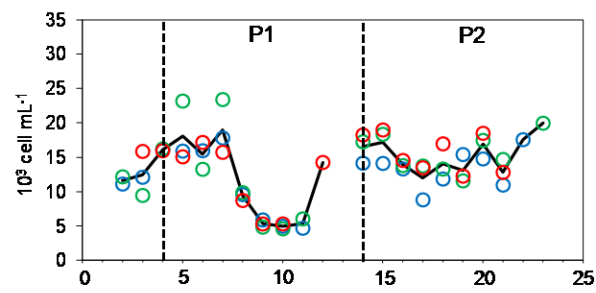

UCYN-C

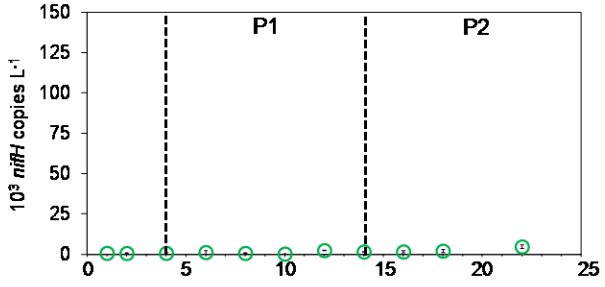

M1

(d)

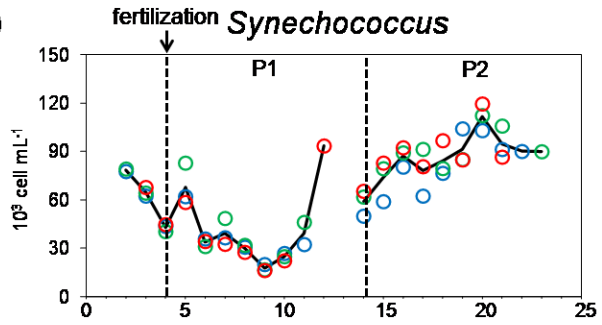

(f)

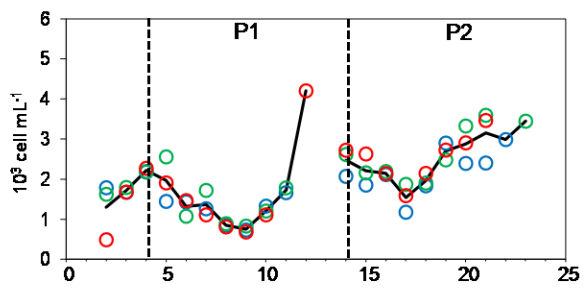

(g)

Nanoeukaryotes

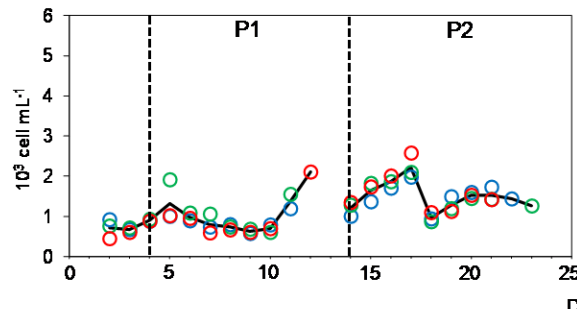

Day of sampling

Figure 4. Evolution of the abundance of (a) diatoms-diazotrophs associations (DDAs) and (b) unicellular diazotrophic cyanobacteria Group $\mathrm{C}(\mathrm{UCYN}-\mathrm{C})\left(\times 10^{3}\right.$ nifH copies $\left.\mathrm{L}^{-1}\right)$ in the mesocosm M1 and in the surrounding waters $(\mathrm{OUT})$, and $(\mathbf{c})$ total diatoms $\left(\times 10^{3}\right.$ cell $\left.\mathrm{L}^{-1}\right)$, (d) Synechoccocus spp., (e) Prochloroccocus spp., (f) picoeukaryotes and (g) nanoeukaryotes $\left(\times 10^{3}\right.$ cell $\left.\mathrm{mL}^{-1}\right)$ in the mesocosm M1 only, over the course of the 23-day experiment. Synechoccocus spp., Prochloroccocus spp., picoeukaryotes and nanoeukaryotes were determined at 1, 6 and $12 \mathrm{~m}$ depths, while DDAs, UCYN-C and total diatoms were determined solely at $6 \mathrm{~m}$ depth. For DDAs and UCYN-C, dots are mean values with standard deviations from duplicate measurements. Black line represents the depth-averaged values. P1: first part of the experiment, from day 5 to day 14; P2: second part of the experiment, from day 15 to day 23. Detailed data about diazotrophs (DDAs and UCYN-C) are found in Turk-Kubo et al. (2015). 
Table 1. Mean values and associated standard deviations of chromophoric, biogeochemical and biological parameters of samples collected in the mesocosm M1 and in the surrounding waters (OUT) during the first part of the experiment, i.e. from day 5 to day 14 (P1), and during the second part of the experiment, i.e. from day 15 to day 23 (P2). The means which have different letters (a, b, c or d) are significantly different (ANOVA, $p<0.05$ ). M1-P2 values in bold are significantly different from M1-P1, OUT-P1 and OUT-P2 values.

\begin{tabular}{|c|c|c|c|c|}
\hline & M1-P1 (n) & $\mathrm{M} 1-\mathrm{P} 2(n)$ & OUT-P1 (n) & OUT-P2 (n) \\
\hline TChl $a\left(\mu \mathrm{g} \mathrm{L}^{-1}\right)$ & $0.19 \pm 0.05^{\mathrm{a}}(28)$ & $\mathbf{0 . 4 2} \pm \mathbf{0 . 1 4}{ }^{\mathrm{b}}(27)$ & $0.21 \pm 0.03^{\mathrm{a}}(25)$ & $0.30 \pm 0.07^{\mathrm{c}}(25)$ \\
\hline Phycoerythrin $\left(\mu \mathrm{g} \mathrm{L}^{-1}\right)$ & $0.17 \pm 0.09^{\mathrm{a}}(9)$ & $0.24 \pm 0.09^{\mathrm{a}}(9)$ & $0.19 \pm 0.08^{\mathrm{a}}(10)$ & $0.42 \pm 0.19^{\mathrm{b}}(9)$ \\
\hline $\mathrm{TOC}(\mu \mathrm{M})$ & $66.5 \pm 2.1^{\mathrm{a}}(9)$ & $69.7 \pm 4.3^{\mathrm{b}}(9)$ & $66.6 \pm 2.8^{\mathrm{a}}(9)$ & $67.7 \pm 1.5^{\mathrm{a}, \mathrm{b}}(7)$ \\
\hline $\mathrm{PON}(\mu \mathrm{M})$ & $0.81 \pm 0.13^{\mathrm{a}}(30)$ & $\mathbf{1 . 1 0} \pm \mathbf{0 . 2 1}^{\mathrm{b}}(27)$ & $0.71 \pm 0.06^{\mathrm{c}}(30)$ & $0.87 \pm 0.13^{\mathrm{a}}(27)$ \\
\hline $\mathrm{DON}(\mu \mathrm{M})$ & $5.5 \pm 1.4^{\mathrm{a}}(29)$ & $4.8 \pm 0.6^{\mathrm{a}}(22)$ & $5.0 \pm 0.4^{\mathrm{a}}(29)$ & $5.3 \pm 1.8^{\mathrm{a}}(23)$ \\
\hline $\mathrm{BP}\left(\mathrm{ngCL^{-1 }} \mathrm{h}^{-1}\right)$ & $157 \pm 49^{\mathrm{a}}(30)$ & $348 \pm 142^{b}(27)$ & $135 \pm 24^{\mathrm{a}}(30)$ & $256 \pm 60^{c}(27)$ \\
\hline DDAs $\left(\times 10^{3}\right.$ nifH copies $\left.\mathrm{L}^{-1}\right)$ & $120 \pm 45^{\mathrm{a}, \mathrm{b}}(5)$ & $54 \pm 31^{\mathrm{a}}(6)$ & $227 \pm 189^{\mathrm{b}, \mathrm{c}}(5)$ & $200 \pm 220^{\mathrm{a}, \mathrm{c}}(3)$ \\
\hline UCYN-C $\left(\times 10^{3}\right.$ nifH copies $\left.\mathrm{L}^{-1}\right)$ & $4.5 \pm 7.6^{\mathrm{a}}(4)$ & $64 \pm 24^{b}(6)$ & $1.2 \pm 0.8^{\mathrm{a}}(5)$ & $2.9 \pm 1.7^{\mathrm{a}}(3)$ \\
\hline Total diatoms $\left(\times 10^{3}\right.$ cell $\left.\mathrm{L}^{-1}\right)$ & $17 \pm 9^{a}(5)$ & $44 \pm 37^{\mathrm{a}}(5)$ & nd & nd \\
\hline Synechococcus $\left(\times 10^{3}\right.$ cell $\left.\mathrm{mL}^{-1}\right)$ & $41 \pm 20^{\mathrm{a}}(24)$ & $\mathbf{8 8} \pm 14^{b}(23)$ & nd & nd \\
\hline Prochlorococcus $\left(\times 10^{3}\right.$ cell $\left.\mathrm{mL}^{-1}\right)$ & $12 \pm 6^{\mathrm{a}}(24)$ & $15 \pm 3^{\mathrm{a}}(23)$ & nd & nd \\
\hline Picoeukaryotes $\left(\times 10^{3}\right.$ cell $\left.\mathrm{mL}^{-1}\right)$ & $1.5 \pm 0.8^{\mathrm{a}}(24)$ & $\mathbf{2 . 4} \pm \mathbf{0 . 6}^{\mathrm{b}}(23)$ & nd & nd \\
\hline Nanoeukaryotes $\left(\times 10^{3}\right.$ cell $\left.\mathrm{mL}^{-1}\right)$ & $0.9 \pm 0.4^{\mathrm{a}}(24)$ & $1.5 \pm 0.4^{b}(23)$ & nd & nd \\
\hline$a_{\mathrm{g}}(370)\left(\mathrm{m}^{-1}\right)$ & $0.046 \pm 0.004^{\mathrm{a}}(30)$ & $\mathbf{0 . 0 5 8} \pm \mathbf{0 . 0 0 9}^{\mathrm{b}}(27)$ & $0.049 \pm 0.005^{\mathrm{a}, \mathrm{c}}(9)$ & $0.052 \pm 0.006^{\mathrm{c}}(9)$ \\
\hline$a_{\mathrm{g}}(442)\left(\mathrm{m}^{-1}\right)$ & $0.013 \pm 0.001^{\mathrm{a}}(30)$ & $0.016 \pm 0.003^{\mathrm{b}}(27)$ & $0.015 \pm 0.002^{\mathrm{a}, \mathrm{c}}(9)$ & $0.015 \pm 0.001^{\mathrm{c}, \mathrm{b}}(9)$ \\
\hline$S_{\mathrm{g}}\left(\mathrm{nm}^{-1}\right)$ & $0.0172 \pm 0.001^{\mathrm{a}, \mathrm{b}}(30)$ & $0.0174 \pm 0.001^{\mathrm{b}}(27)$ & $0.0169 \pm 0.001^{\mathrm{a}}(9)$ & $0.0169 \pm 0.001^{\mathrm{a}}(9)$ \\
\hline$a_{\mathrm{p}}(442)\left(\mathrm{m}^{-1}\right)$ & $0.014 \pm 0.004^{\mathrm{a}}(30)$ & $\mathbf{0 . 0 2 2} \pm \mathbf{0 . 0 0 4} 4^{\mathrm{b}}(27)$ & $0.015 \pm 0.002^{\mathrm{a}}(9)$ & $0.018 \pm 0.002^{\mathrm{c}}(9)$ \\
\hline$a_{\mathrm{p}}(676)\left(\mathrm{m}^{-1}\right)$ & $0.005 \pm 0.002^{\mathrm{a}}(30)$ & $0.009 \pm 0.002^{\mathrm{b}}(27)$ & $0.005 \pm 0.001^{\mathrm{a}}(9)$ & $0.008 \pm 0.001^{\mathrm{b}}(9)$ \\
\hline Humic-like (QSU) & $4.47 \pm 0.76^{\mathrm{a}}(30)$ & $4.45 \pm 1.09^{\mathrm{a}}(18)$ & nd & nd \\
\hline Tryptophan-like (QSU) & $7.68 \pm 1.17^{\mathrm{a}}(30)$ & $8.07 \pm 2.07^{\mathrm{a}}(18)$ & nd & nd \\
\hline Tyrosine-like (QSU) & $6.57 \pm 1.21^{\mathrm{a}}(28)$ & $5.49 \pm \mathbf{0 . 8 3}^{\mathrm{b}}(18)$ & nd & nd \\
\hline
\end{tabular}

nd: not determined; TChl $a$ : total chlorophyll $a$ concentration; TOC: total organic carbon concentration; PON and DON: particulate and dissolved organic nitrogen concentrations; BP: bacterial production; DDAs: diatoms-diazotrophs associations; UCYN-C: unicellular diazotrophic cyanobacteria Group C; $a_{\mathrm{g}}(370)$ and $a_{\mathrm{g}}(442)$ : absorption coefficients of CDOM at 370 and $442 \mathrm{~nm} ; S_{\mathrm{g}}$ : spectral slope of CDOM; $a_{\mathrm{p}}(442)$ and $a_{\mathrm{p}}(676)$ : absorption coefficients of particulate matter at 442 and $676 \mathrm{~nm}$; Humic-like, tryptophan-like and tyrosine-like: fluorescence intensity of humic-like, tryptophan-like and tyrosine-like FDOM fluorophores. Detailed data about diazotrophs (DDAs and UCYN-C) are found in Turk-Kubo et al. (2015).

(Fig. 5). Hereafter, $a_{\mathrm{g}}(\lambda)$ is presented at 370 and $442 \mathrm{~nm}$, while $a_{\mathrm{p}}(\lambda)$ is given at 442 and $676 \mathrm{~nm}$, the two latter wavelengths corresponding to the absorption maxima of Chl $a$.

\subsection{Evolution of absorption coefficients, spectral slope in the mesocosm}

In M1, absorption coefficients decreased from day 4 to day 9 and then increased from day 9 to the end of the experiment (day 23), leading to variations in the ranges $0.041-0.067 \mathrm{~m}^{-1}$ for $a_{\mathrm{g}}(370), 0.011-0.020 \mathrm{~m}^{-1}$ for $a_{\mathrm{g}}(442), 0.009-0.025 \mathrm{~m}^{-1}$ for $a_{\mathrm{p}}(442)$ and $0.003-0.012 \mathrm{~m}^{-1}$ for $a_{\mathrm{p}}(676)$ (Fig. 6a, b, d, e). In OUT, these parameters also increased from day 9 or 10 to day 23 but with lower amplitude. Inside M1, all these absorption coefficients were significantly higher during P2 than during P1 (ANOVA, $n=27-30, p<0.0001$ ). However, only $a_{\mathrm{g}}(370)$ and $a_{\mathrm{p}}(442)$ were significantly higher in M1 than outside during P2 (ANOVA, $n=9-27, p=0.004-0.02$ ) (Table 1). $S_{\mathrm{g}}$ inside and outside $\mathrm{M} 1$, ranging from 0.0148 to $0.0188 \mathrm{~nm}^{-1}$, did not display any clear pattern throughout the experiment (Fig. 6c).

\subsection{Spectral characteristics and identification of FDOM components}

Three FDOM components $(\mathrm{C} 1-\mathrm{C} 3)$ were identified by the PARAFAC model validated on 130 EEM samples from M1 and OUT. The spectral characteristics of $\mathrm{C} 1-\mathrm{C} 3$ are reported in Fig. 7. These components exhibited one or two Ex maxima and one Em maximum. $\mathrm{C} 1$, with a maximum at $\lambda_{\mathrm{Ex}} / \lambda_{\mathrm{Em}}$ of $230 / 476 \mathrm{~nm}$, corresponded to the category of ultraviolet C (UVC) humic-like fluorophores, referred to as peak A (Coble, 1996, 2007; Ishii and Boyer, 2012). C2 and C3 had two maxima each, located at $\lambda_{\mathrm{Ex} 1}, \lambda_{\mathrm{Ex} 2} / \lambda_{\mathrm{Em}}$ of $225,280 / 344$ and $225,275 / 304 \mathrm{~nm}$, respectively (Fig. 7). They belonged to the group of protein-like fluorophores, $\mathrm{C} 2$ being analogous to tryptophan-like fluorophore (peaks T) and C3 being analogous to tyrosine-like fluorophore (peaks B) (Coble, 1996, 2007).

\subsection{Evolution of FDOM components in the mesocosm M1}

Inside M1, the fluorescence intensity of humic-like fluorophore decreased from day $2(\sim 5.3 \mathrm{QSU})$ to day 8 


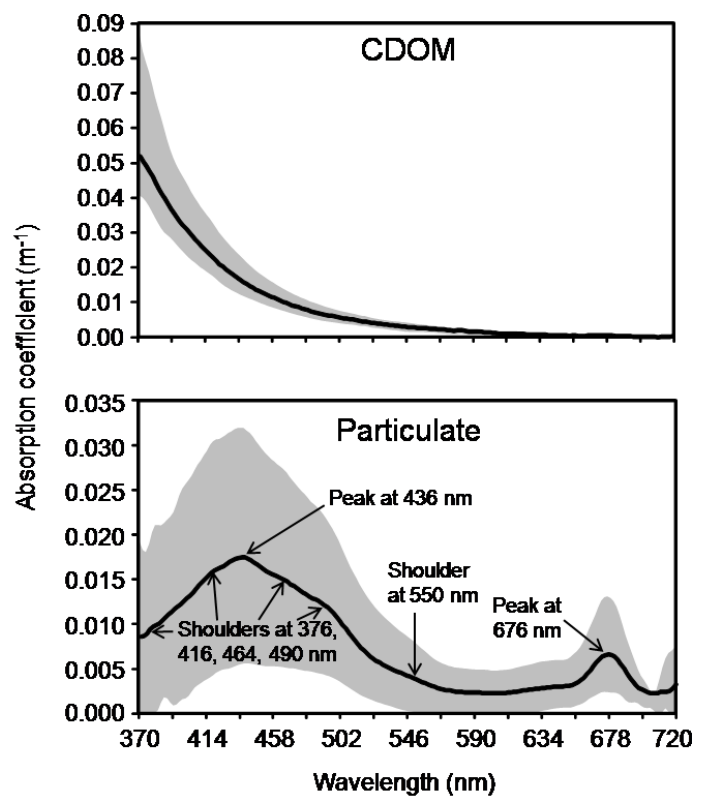

Figure 5. Absorption spectra of chromophoric dissolved organic matter (CDOM) and particulate matter over the ranges 370-720 nm of samples collected in the mesocosm M1 at 1, 6 and $12 \mathrm{~m}$ depths and in the surrounding waters at $1 \mathrm{~m}$ depth. Black lines represent the average of all spectra and shaded areas represent the measured minimal and maximal values. Peaks and shoulders are reported for particulate matter.

( 2.7 QSU), increased from day 8 to day $14(\sim 4.8 \mathrm{QSU})$ and dropped down to $\sim 2.5 \mathrm{QSU}$ at day 15 . Then, it increased to reach $\sim 5.6$ QSU at day 20 (Fig. 8a). The fluorescence intensity of tryptophan-like fluorophore decreased from day $3(\sim 9.1 \mathrm{QSU})$ to day $8(\sim 5.3 \mathrm{QSU})$ (Fig. $8 \mathrm{~b})$. At day 9 , it increased up to $\sim 8.3$ QSU and remained relatively stable up to day $14(\sim 8.4 \mathrm{QSU})$. After a reduction at day $15(\sim 5.9$ QSU), the fluorescence intensity increased up to the end of the experiment $(\sim 10.4 \mathrm{QSU}$ at day 20$)$. The fluorescence intensity of tyrosine-like fluorophore decreased from day $5(\sim 8.2 \mathrm{QSU})$ to day $15(\sim 3.9 \mathrm{QSU})$ and then slowly increased to day $20(\sim 6.2$ QSU) (Fig. 8c). While for humic- and tryptophan-like fluorophores no differences in their fluorescence intensity were observed between P1 and P2 (ANOVA, $n=18-30, p=0.4-0.9$ ), the fluorescence intensity of tyrosine-like fluorophore was significantly lower during P2 (ANOVA, $n=18-28, p=0.002$ ) (Table 1). Overall, the FDOM pool was dominated by protein-like material: the combined fluorescence of tryptophan and tyrosine fluorophores ranged from 9.1 to $22.3 \mathrm{QSU}$, while the fluorescence of humic fluorophore ranged from 1.9 to $6.2 \mathrm{QSU}$.

\subsection{Relationships between the chromophoric and the biogeochemical/biological parameters}

Table 2 presents $r$ values of linear regressions between the chromophoric and the biogeochemical/biological pa- rameters for the samples collected in M1 from day 5 to day 20 . Here we consider that only the correlations that are very highly significant $(p<0.0001)$ reflect relevant linear relationships. $a_{\mathrm{g}}(370,442)$ and $a_{\mathrm{p}}(442,676)$ were not that much correlated to each other $(r=0.52-0.62, n=36$, $p<0.0001-0.002) . S_{\mathrm{g}}$ was not correlated to $a_{\mathrm{g}}(370,442)$ $(r=0.15-0.22, n=36, p=0.06-0.9)$. Even though humicand tryptophan-like fluorophores were very highly correlated $(r=0.67, n=36, p<0.0001)$, they did not show any coupling with tyrosine-like fluorophore $(r=0.20-0.48, n=36$, $p=0.005-0.2)$. Moreover, none of these three fluorophores was very highly correlated to the absorption coefficients and spectral slope $(r=0.09-0.42, n=36, p>0.5-0.05)$ (Table 2). These correlations emphasize the decoupling between the CDOM and FDOM materials during the experiment.

All absorption coefficients were very highly positively correlated to Synechococcus spp. abundance $(r=0.76-0.83)$, BP $(r=0.72-0.78)$, TChl $a$ concentration $(r=0.60-0.88)$, PON concentration $(r=0.58-0.75)$ and picoeukaryote abundance $(r=0.52-0.71)(n=36, p<0.0001)$. Linear relationships between $a_{\mathrm{g}}(370)$ or $a_{\mathrm{p}}(442)$ and Synechococcus spp. abundance are presented in Fig. 9. $S_{\mathrm{g}}$ as well as the three FDOM fluorophores did not present any highly significant correlation with the biogeochemical/biological constituents. Phycoerythrin, TOC, DDAs, UCYN-C and total diatoms did not display any very highly significant correlations with the chromophoric parameters, although some $r$ values were quite high (for instance 0.90 between UCYN-C and $a_{\mathrm{p}}(442)$ ). This is because these correlations were determined for a lower number of samples (8-15). Nonetheless these relationships highlighted interesting, albeit not very highly significant, trends such as positive (negative) relationships between absorption coefficients (tyrosine-like fluorophore) and UCYN$\mathrm{C}$ abundance as well as negative (positive) relationships between absorption coefficients (tyrosine-like fluorophore) and DDA abundance (Table 2).

\section{Discussion}

\subsection{General characteristics of chromophoric material}

\subsubsection{CDOM absorption}

CDOM absorption spectra from samples inside and outside the mesocosm did not display any significant shoulder in the range 370-720 nm (Fig. 5). In the same way, using the PSICAM, Röttgers and Koch (2012) did not observe any specific feature in the CDOM absorption spectra from 380 to $700 \mathrm{~nm}$ of samples collected in the surface waters of the tropical Atlantic Ocean and of the north-east and south-west Pacific, including our study area inside the barrier reef of New Caledonia.

$a_{\mathrm{g}}(370)$ and $a_{\mathrm{g}}(442)$ measured inside and outside the mesocosm $\left(0.040-0.086\right.$ and $0.011-0.022 \mathrm{~m}^{-1}$, respectively; 

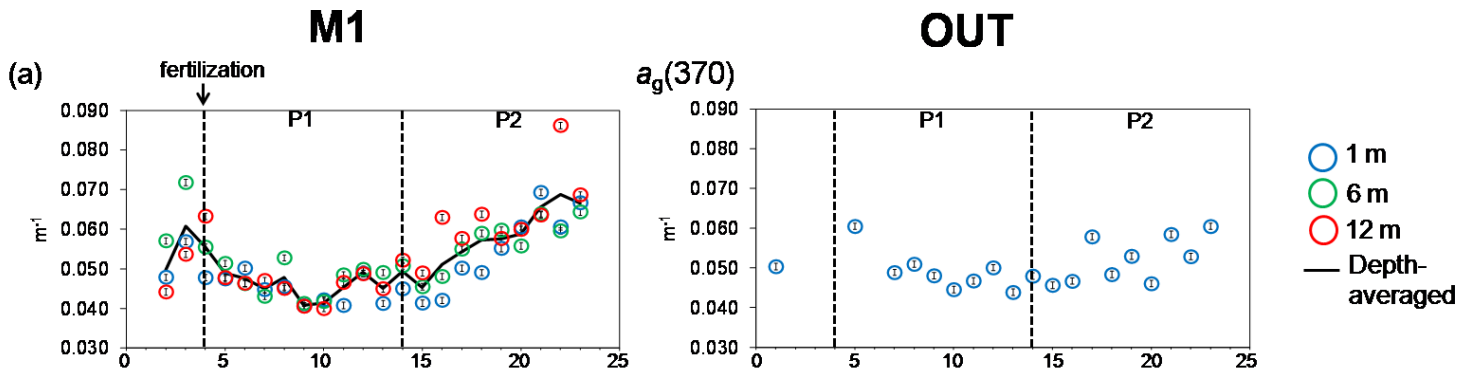

(b)

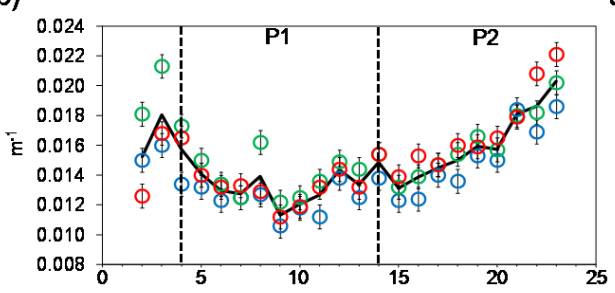

(c)

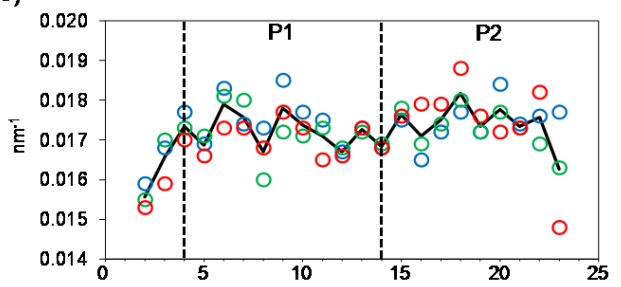

$a_{g}(442)$

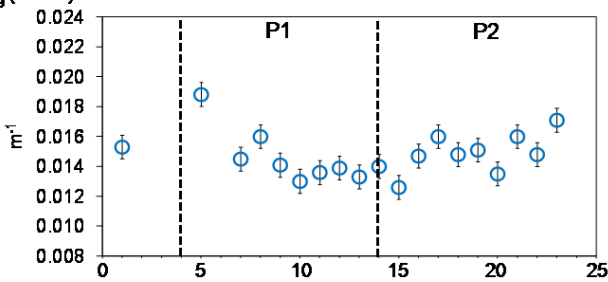

$S_{\mathrm{g}}$

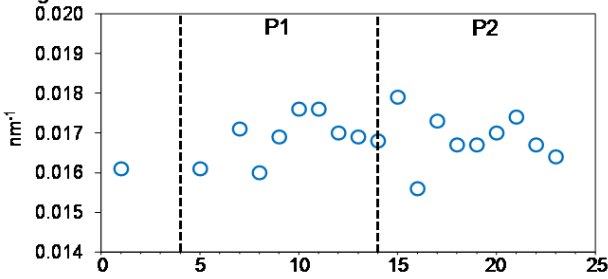

(d)

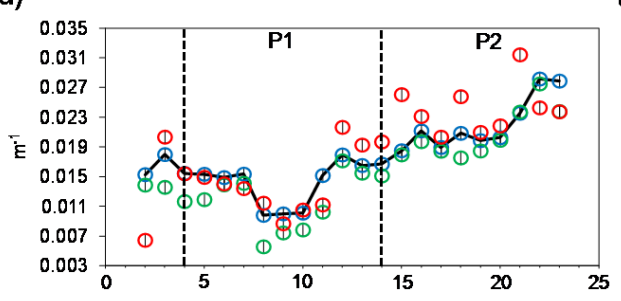

$a_{\mathrm{p}}(442)$

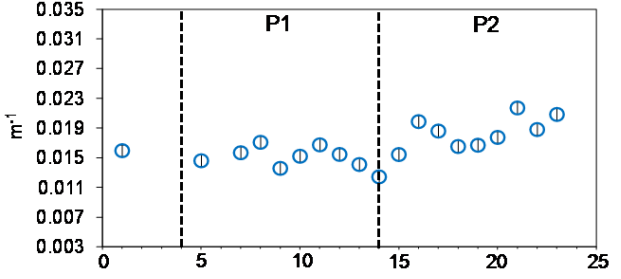

$a_{\mathrm{p}}(676)$

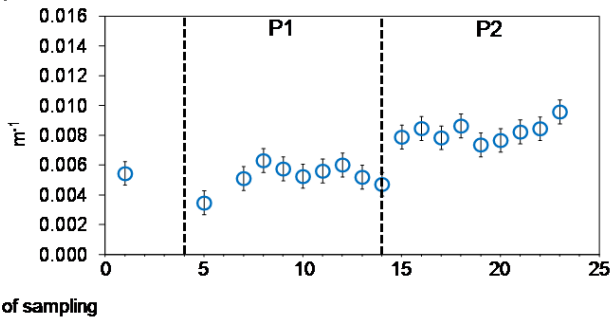

Day of sampling (e)

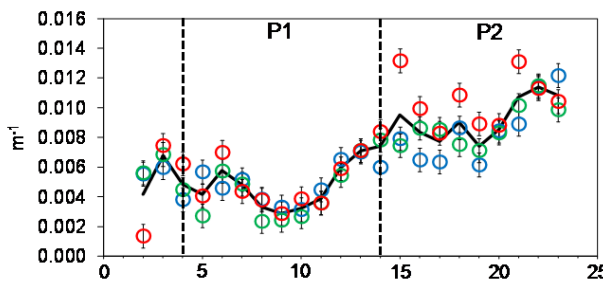

Figure 6. Evolution of (a) absorption coefficient of CDOM at $370 \mathrm{~nm}\left[a_{\mathrm{g}}(370) \mathrm{in} \mathrm{m}^{-1}\right]$, (b) absorption coefficient of CDOM at $442 \mathrm{~nm}$ $\left[a_{\mathrm{g}}(442) \mathrm{in} \mathrm{m}^{-1}\right]$, (c) spectral slope of CDOM absorption in the range $370-500 \mathrm{~nm}\left(S_{\mathrm{g}} \mathrm{in} \mathrm{nm}^{-1}\right)$, (d) absorption coefficient of particulate matter at $442 \mathrm{~nm}\left[a_{\mathrm{p}}(442) \mathrm{in} \mathrm{m}^{-1}\right]$ and (e) absorption coefficient of particulate matter at $676 \mathrm{~nm}\left[a_{\mathrm{p}}(676) \mathrm{in} \mathrm{m}^{-1}\right]$ in the mesocosm M1 at 1,6 and $12 \mathrm{~m}$ depths and in the surrounding waters (OUT) at $1 \mathrm{~m}$ depth over the course of the 23 -day experiment. Dots are mean values with standard deviations from duplicate measurements, except for $S_{\mathrm{g}}$. Black line represents the depth-averaged values. P1: first part of the experiment, from day 5 to day 14; P2: second part of the experiment, from day 15 to day 23. 
Table 2. Pearson's correlation coefficients $(r)$ of linear regressions between the chromophoric and the biogeochemical/biological parameters of samples collected in the mesocosm M1 from day 5 to day 20, i.e. from the day after the dissolved inorganic phosphorus fertilization to almost the end of the experiment $(\mathrm{P} 1+\mathrm{P} 2)(n=36)$.

\begin{tabular}{lrrrrrrrr}
\hline & $a_{\mathrm{g}}(370)$ & $a_{\mathrm{g}}(442)$ & $S_{\mathrm{g}}$ & $a_{\mathrm{p}}(442)$ & $a_{\mathrm{p}}(676)$ & Humic & Trypto. & Tyrosine \\
\hline$a_{\mathrm{g}}(442)$ & $\mathbf{0 . 9 0}$ & & & & & & & \\
$S_{\mathrm{g}}$ & 0.22 & -0.15 & & & & & & \\
$a_{\mathrm{p}}(442)$ & $\mathbf{0 . 6 1}$ & 0.52 & 0.23 & & & & & \\
$a_{\mathrm{p}}(676)$ & $\mathbf{0 . 6 2}$ & 0.53 & 0.30 & $\mathbf{0 . 9 3}$ & & & & \\
Humic & 0.42 & 0.36 & 0.13 & 0.22 & 0.10 & & & \\
Trypto. & 0.28 & 0.24 & 0.28 & 0.17 & 0.16 & $\mathbf{0 . 6 7}$ & & \\
Tyrosine & -0.09 & -0.25 & 0.11 & -0.28 & -0.39 & 0.48 & 0.20 & \\
TChl $a$ & $\mathbf{0 . 6 8}$ & $\mathbf{0 . 6 0}$ & 0.32 & $\mathbf{0 . 8 6}$ & $\mathbf{0 . 8 8}$ & 0.22 & 0.21 & -0.33 \\
Phyco. & 0.45 & 0.42 & 0.11 & 0.74 & 0.73 & 0.05 & 0.00 & -0.35 \\
TOC* & 0.35 & 0.16 & 0.63 & 0.57 & 0.59 & 0.52 & 0.43 & 0.28 \\
PON & $\mathbf{0 . 7 1}$ & $\mathbf{0 . 5 8}$ & 0.29 & $\mathbf{0 . 7 5}$ & $\mathbf{0 . 7 0}$ & 0.43 & 0.29 & 0.04 \\
DON & -0.30 & -0.23 & -0.13 & -0.14 & -0.04 & -0.26 & -0.10 & -0.14 \\
BP & $\mathbf{0 . 7 5}$ & $\mathbf{0 . 7 2}$ & 0.10 & $\mathbf{0 . 7 8}$ & $\mathbf{0 . 7 2}$ & 0.43 & 0.32 & -0.12 \\
DDAs* & -0.44 & -0.38 & -0.52 & -0.85 & -0.78 & 0.20 & 0.05 & 0.60 \\
UCYN-C* & 0.73 & 0.67 & 0.55 & 0.90 & 0.85 & 0.15 & 0.23 & -0.47 \\
Diatoms* & -0.07 & -0.08 & 0.40 & 0.49 & 0.47 & -0.85 & -0.74 & -0.88 \\
Synecho. & $\mathbf{0 . 7 6}$ & $\mathbf{0 . 7 6}$ & 0.08 & $\mathbf{0 . 8 3}$ & $\mathbf{0 . 7 6}$ & 0.35 & 0.29 & -0.27 \\
Prochlo. & 0.42 & 0.47 & 0.08 & 0.57 & 0.50 & 0.13 & 0.03 & 0.00 \\
Picoeuka. & 0.52 & $\mathbf{0 . 6 2}$ & -0.07 & $\mathbf{0 . 7 1}$ & $\mathbf{0 . 5 8}$ & 0.40 & 0.34 & -0.25 \\
Nanoeuka. & 0.48 & 0.45 & 0.01 & $\mathbf{0 . 6 5}$ & $\mathbf{0 . 5 8}$ & 0.11 & 0.01 & -0.35 \\
\hline Con & & & & & & & & \\
\hline
\end{tabular}

Correlation coefficients $(r)$ in bold are very highly significant $(p<0.0001) *$ Correlations determined on a lower number of samples $(n)$ : 15 for Phyco. and TOC, 10 for DDAs, 9 for UCYN-C and 8 for diatoms. $a_{\mathrm{g}}(370)$ and $a_{\mathrm{g}}(442)$ : absorption coefficients of CDOM at 370 and $442 \mathrm{~nm}\left(\mathrm{~m}^{-1}\right) ; S_{\mathrm{g}}$ : spectral slope of CDOM; $a_{\mathrm{p}}(442)$ and $a_{\mathrm{p}}(676)$ : absorption coefficients of particulate matter at 442 and $676 \mathrm{~nm}\left(\mathrm{~m}^{-1}\right)$; Humic: fluorescence intensity of humic-like fluorophore (QSU); Trypto.: fluorescence intensity of tryptophan-like fluorophore (QSU); Tyrosine: fluorescence intensity of tyrosine-like fluorophore (QSU); TChl $a$ : total chlorophyll $a$ concentration $\left(\mu \mathrm{g} \mathrm{L}^{-1}\right)$; Phyco.: phycoerythrin concentration $\left(\mu \mathrm{g} \mathrm{L}^{-1}\right)$; TOC: total organic carbon concentration $(\mu \mathrm{M})$; PON and DON: particulate and dissolved organic nitrogen concentrations $(\mu \mathrm{M})$; BP: bacterial production $\left(\mathrm{ng} \mathrm{CL}^{-1} \mathrm{~h}^{-1}\right)$; DDAs: diatoms-diazotrophs associations ( iff $H$ copies $\mathrm{L}^{-1}$ ); UCYN-C: unicellular diazotrophic cyanobacteria Group C (nifH copies $\mathrm{L}^{-1}$ ); Diatoms: total diatoms (cell $\mathrm{L}^{-1}$ ); Synecho.: Synechococcus spp. (cell $\mathrm{mL}^{-1}$ ); Prochlo.: Prochlorococcus spp. (cell $\left.\mathrm{mL}^{-1}\right)$; Picoeuka.: Picoeukaryote $\left(\right.$ cell $\left.\mathrm{mL}^{-1}\right)$; Nanoeuka.: Nanoeukaryote $\left(\right.$ cell $\left.\mathrm{mL}^{-1}\right)$. Detailed data about diazotrophs (DDAs and UCYN-C) are found in Turk-Kubo et al. (2015).

Fig. 6a, b) were within the range of those measured in surface waters of the Atlantic Ocean and at 80-200 m depth in the south-west Pacific (offshore of New Caledonia) (0.0210.118 and $0.004-0.039 \mathrm{~m}^{-1}$, respectively) (Röttgers and Doerffer, 2007; Röttgers and Koch, 2012; Dupouy et al., 2014). In addition, our $a_{\mathrm{g}}(370)$ and $a_{\mathrm{g}}(442)$ values were slightly lower than those measured in the subtropical North Pacific and the Mediterranean Sea (0.050-0.090 and 0.018$0.035 \mathrm{~m}^{-1}$, respectively) (Yamashita et al., 2013; Organelli et al., 2014) but higher than those observed in the center of the gyre of the south-east Pacific (>0.010-0.035 and 0.005$0.015 \mathrm{~m}^{-1}$, respectively) (Bricaud et al., 2010).

Our $S_{\mathrm{g}}$ values determined over the range $370-500 \mathrm{~nm}$ varied between 0.015 and $0.019 \mathrm{~nm}^{-1}$ inside and outside the mesocosm (Fig. 6c). They were to some extent lower than $S_{\mathrm{g}}$ values determined between 350 and $500 \mathrm{~nm}$ of surface waters of the Mediterranean Sea, Atlantic Ocean and south-east Pacific (0.015-0.025 $\mathrm{nm}^{-1}$ ) (Röttgers and Doerffer, 2007; Bricaud et al., 2010; Para et al., 2010; Organelli et al., 2014). In fact, our $S_{\mathrm{g}}$ values did not reach the maximal values en- countered in oligotrophic areas $\left(0.020-0.025 \mathrm{~nm}^{-1}\right)$ despite the potentially important CDOM photobleaching processes which would have occurred in the surface waters of the mesocosm. This is explained by the different spectral ranges used for the $S_{\mathrm{g}}$ determination $(370-500 \mathrm{~nm}$ vs. $350-500 \mathrm{~nm})$. Indeed, $S_{\mathrm{g}}$, which strongly depends on the chosen wavelength interval, is generally higher for intervals in the short wavelengths (Nelson and Siegel, 2013; Sempéré et al., 2015), and do not present a constant spectral slope but rather steeper slopes towards the short UV wavelengths (Tedetti et al., 2007; Sempéré et al., 2015). Hence, this difference of $20 \mathrm{~nm}$ in the wavelength interval may influence the $S_{\mathrm{g}}$ values, the latter decreasing when considering the range $370-500 \mathrm{~nm}$. It is worth noting that no correlation was found between $a_{\mathrm{g}}(370)$ or $a_{\mathrm{g}}(442)$ and $S_{\mathrm{g}}$ (Table 2 ). This was probably attributable to the low ranges and the low values of both $a_{\mathrm{g}}(\lambda)$ and $S_{\mathrm{g}}$ reported here. 

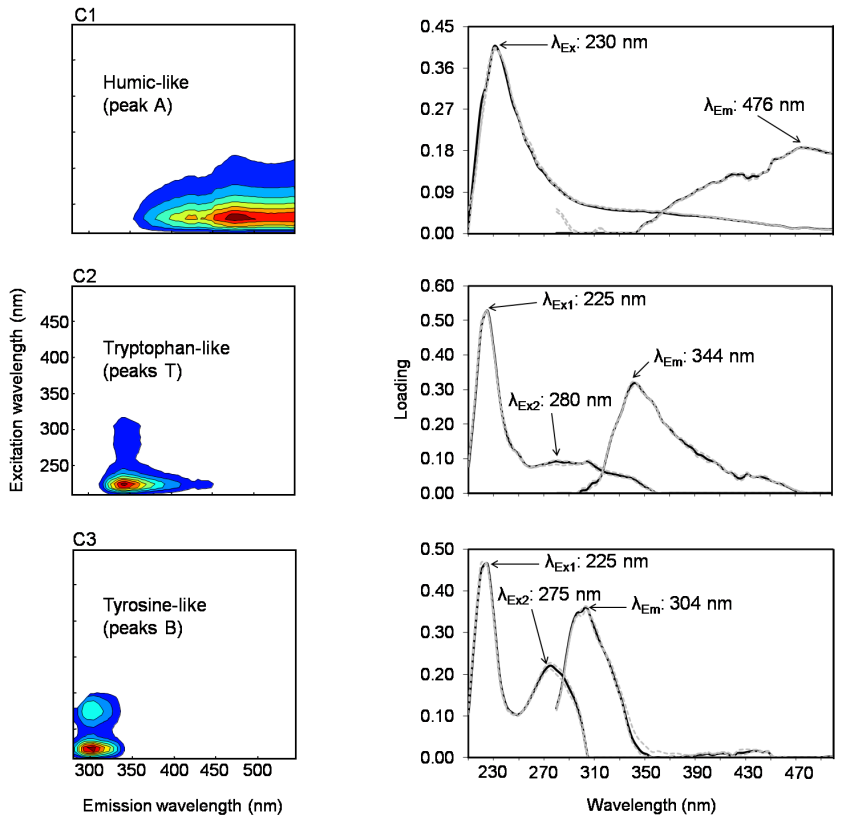

Figure 7. Spectral characteristics of the three FDOM components (C1-C3) validated by the PARAFAC model for 130 EEMs of samples collected in the mesocosm M1 at 1, 6 and $12 \mathrm{~m}$ depths and in the surrounding waters at $1 \mathrm{~m}$ depth over the course of the 23day experiment. Both contour (left column) and line (right column) plots are depicted. The line plots show the excitation (left side) and emission (right side) fluorescence spectra. The dotted grey lines correspond to split half validation results. The excitation and emission maxima $\left(\lambda_{\mathrm{Ex}}\right.$ and $\left.\lambda_{\mathrm{Em}}\right)$ of each component are given.

\subsubsection{FDOM}

The three FDOM components identified in this work were UVC humic-, tryptophan- and tyrosine-like fluorophores (Fig. 7). Thus, FDOM was dominated by protein-like material, i.e. compounds containing nitrogen, while humiclike material was less represented. Of these protein-like compounds, tryptophan- and tyrosine-like fluorophores have been reported in many aquatic ecosystems (see reviews by Coble, 2007; Fellman et al., 2010). They represent compounds of low molecular weight at the state of free amino acids or amino acids bound in peptides or proteins. They are known to be released by autochthonous (marine) phytoplankton activity and serve as fresh and labile bioavailable products for heterotrophic bacteria (Yamashita and Tanoue, 2004; Nieto-Cid et al., 2006; Davis and Benner, 2007; RomeraCastillo et al., 2010; Tedetti et al., 2012). Moreover, they can be directly associated to humic substances (Stedmon and Cory, 2014). Generally, they do not show any conservative behaviour in the salinity gradient (Kowalczuk et al., 2009). UVC humic-like fluorophore ("peak A") corresponds to component $1\left(\lambda_{\mathrm{Ex}} / \lambda_{\mathrm{Em}}:<230-260 / 400-500 \mathrm{~nm}\right)$ in the review paper by Ishii and Boyer (2012) and is one of the most widespread humic-like components in the aquatic en- (a)

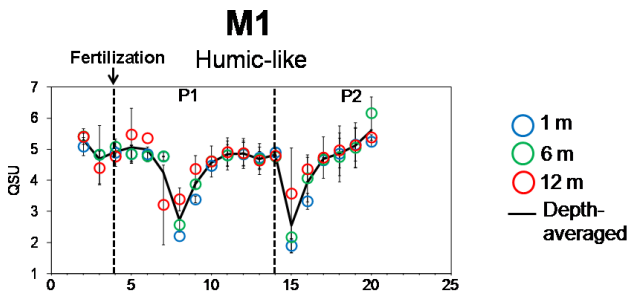

(b)

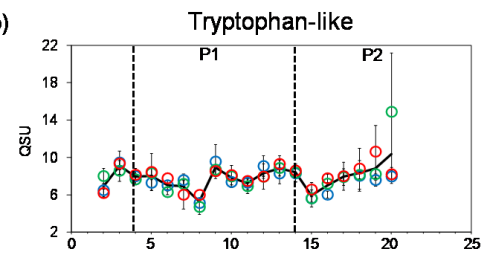

(c)

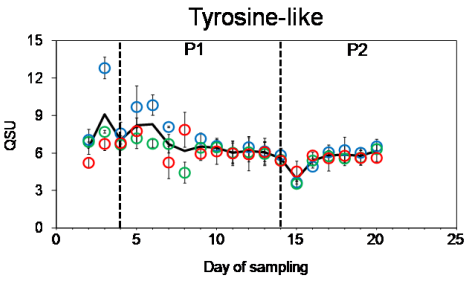

Figure 8. Evolution of the fluorescence intensities (QSU) of the three FDOM components: (a) humic-like, (b) tryptophan-like and (c) tyrosine-like fluorophores in the mesocosm M1 at 1,6 and $12 \mathrm{~m}$ depths over the course of the 23-day experiment (actually up to day 20 and not to day 23). Dots are mean values with standard deviations from duplicate measurements. Black line represents the depthaveraged values. P1: first part of the experiment, from day 5 to day 14; P2: second part of the experiment, from day 15 to day 23 . Fluorescence intensities in the surrounding waters (OUT) at $1 \mathrm{~m}$ depth were determined on only few samples at the beginning and the end of the experiment and are thus not presented here.

vironment (Kowalczuk et al., 2009, 2013). This fluorophore, which absorbs light at very short wavelengths $(230 \mathrm{~nm})$ and fluoresce in long visible wavelengths $(476 \mathrm{~nm})$ resulting in a high Stokes shift ( $246 \mathrm{~nm}$ ), would be of relatively low molecular weight $(<1 \mathrm{kDa})$ compared to other fluorescent humiclike materials (Ishii and Boyer, 2012). Present in higher quantities in the photic zone and shallow surface waters, this humic-like component is recognized as a photodegradation product of marine organic matter (Yamashita et al., 2008; Ishii and Boyer, 2012) and appears to be resistant to biodegradation (Balcarczyk et al., 2009; Fellman et al., 2010; Lønborg et al., 2015).

\subsubsection{Particulate absorption}

Particulate absorption coefficient spectra were dominated by phytoplankton absorption $\left[a_{\phi}(\lambda)\right]$ with the presence of the two main peaks of Chl $a$ (at 436 and $672 \mathrm{~nm}$ ), whereas the influence of detrital material (NAP), characterized by an exponential decrease of absorption with wavelength, was not really visible upon these spectra (Fig. 5). Besides these two 

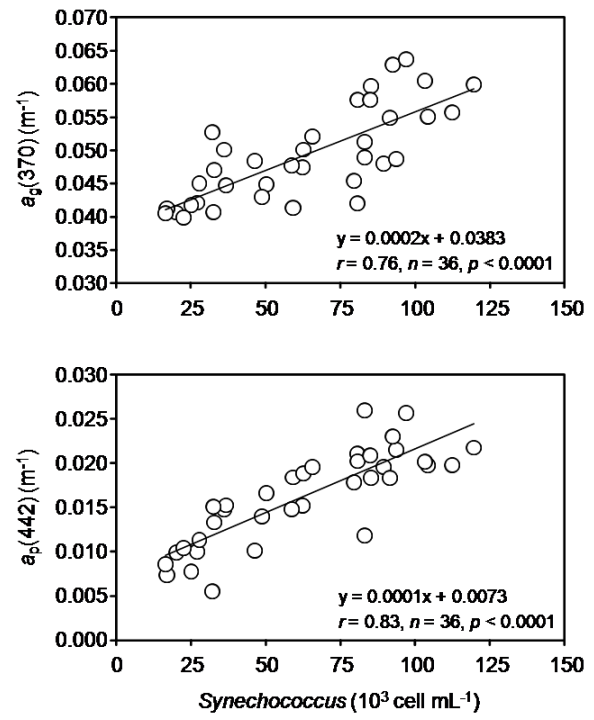

Figure 9. Linear relationships between absorption coefficient of CDOM at $370 \mathrm{~nm}\left[a_{\mathrm{g}}(370) \mathrm{in} \mathrm{m}^{-1}\right]$ or absorption coefficient of particulate matter at $442 \mathrm{~nm}\left[a_{\mathrm{p}}(442)\right.$ in $\left.^{-1}\right]$ and Synechoccocus spp. abundance $\left(\times 10^{3}\right.$ cell $\left.\mathrm{mL}^{-1}\right)$ for samples collected in the mesocosm M1 from day 5 to day 20, i.e. from the day after the dissolved inorganic phosphorus fertilization to almost the end of the experiment $(\mathrm{P} 1+\mathrm{P} 2)(n=36)$.

main peaks, several shoulders were found between 376 and $550 \mathrm{~nm}$. Actually, the shoulders at 376 and $416 \mathrm{~nm}$ might be related to Chl $a$ (Stuart et al., 1998; Lohrenz et al., 2003). The shoulders at 464 and $490 \mathrm{~nm}$ reflected the occurrence of photosynthetic carotenoids and/or non photosynthetic (photoprotective) carotenoids (Dupouy et al., 1997, 2003; Stuart et al., 1998; Wozniak et al., 1999; Lohrenz et al., 2003; Bricaud et al., 2004). In addition, the shoulder at $490 \mathrm{~nm}$ may be related to the presence of phycourobilin (PUB). PUB, which absorbs light around $490 \mathrm{~nm}$, is known to be contained in phycoerythrin of cyanobacteria, such as Synechococcus spp., living in the open ocean. PUB is indeed considered as a chromatic adaptation to blue radiation which penetrates deeper than other wavelengths in the water column (Neveux et al., 1999). Also, the small shoulder at $550 \mathrm{~nm}$ could be the sign of phycoerythrobilin (PEB), also contained in phycoerythrin. PEB, absorbing light around $550-565 \mathrm{~nm}$, is present in higher amount in Synechococcus spp. of coastal environments (Neveux et al., 1999). Pronounced shoulders or peaks at $550 \mathrm{~nm}$ are observed only for exceptional Synechococcus spp. concentrations $\left(>3 \times 10^{5}\right.$ cell mL $\left.{ }^{-1}\right)$ with TChl $a>1 \mu \mathrm{g} \mathrm{L}^{-1}$ (Morel, 1997) or more commonly for large filamentous cyanobacteria in tropical waters (Dupouy et al., 2008). An attribution of the shoulders at 490 and $550 \mathrm{~nm}$ to PUB and PEB, respectively appears reasonable regarding the fact that PUB and PEB signals were detected in the phycoerythrin fluorescence measurements (M. Rodier, personal communication, 2015). Such a proportion of Prochlorococ- cus spp. and Synechococcus spp. counts reported in this work are typical of the New Caledonia lagoon (Neveux et al., 2009) compared to the equatorial upwelling area where this is inverted (Dupouy et al., 2003).

Absorption coefficients of particulate matter at 442 and $676 \mathrm{~nm}\left[a_{\mathrm{p}}(442)\right.$ and $\left.a_{\mathrm{p}}(676)\right]$ measured inside and outside the mesocosm at the mouth of the New Caledonian coral lagoon (0.006-0.031 and $0.0013-0.013 \mathrm{~m}^{-1}$, respectively; Fig. 6d, e) were slightly lower than those measured with the same instrument in the surface waters within the New Caledonian lagoon (0.008-0.040 and $0.0030-0.018 \mathrm{~m}^{-1}$, respectively) (Röttgers et al., 2014; Dupouy et al., 2014), the latter values being linked to an exceptional increase in total phytoplankton biomass during the 2008 Valhybio cruise in response to a La Nina heavy rain episode (Dupouy et al., 2009; Fuchs et al., 2012).

\subsection{Coupling between the dynamics of chromophoric material and that of $\mathbf{N}_{2}$ fixation in the mesocosm}

\subsubsection{Link between absorption and Synechococcus spp.}

Several observations suggest the observed change in particulate matter absorption $\left[a_{\mathrm{p}}(\lambda)\right]$ during the experiment was mainly driven by Synechococcus spp. Several observations may support this hypothesis. Firstly, Synechococcus spp. was the most abundant group among (non-diazotrophic) pico-, nano- and micro-phytoplankton communities in the mesocosm (Fig. 4c-g). For instance, the concentration of

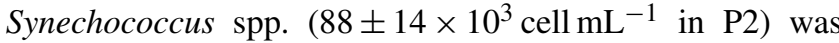
higher by a factor $\sim 1000$ relative to that of total diatoms $\left(44 \pm 37 \times 10^{3}\right.$ cell L $^{-1}$ in P2) (Table 1). Synechococcus spp. abundance cannot, in the first approach, be compared to those of diazotrophs (given in nifH copies $\mathrm{L}^{-1}$ ). However, assuming that there was a minimum of one nifH gene copy per cell, the number of nifH (gene) copies $\mathrm{L}^{-1}$ may reflect the upper limit of the number of cells $\mathrm{L}^{-1}$, though DNA and RNA extractions were probably $<100 \%$ (Foster et al., 2009). In this sense, the concentration of Synechococcus $\mathrm{spp}$. was higher by a factor $\sim 1000$ relative to that of UCYN-C $\left(64 \pm 24 \times 10^{3}\right.$ nifH copies $\mathrm{L}^{-1}$, given a maximum of $64 \pm 24 \times 10^{3}$ cell $\mathrm{L}^{-1}$ in P2) (Table 1). Thus, we conclude that Synechococcus spp. was very likely the most important group among non-diazotrophic and diazotrophic communities in the mesocosm. Secondly, Synechococcus spp. is known to have significant absorption properties in the visible domain, highlighted in culture experiments (Bidigare et al., 1989; Morel et al., 1993; Stramski and Mobley, 1997; Lutz et al., 2001) but also in natural samples (Morel, 1997). Absorption properties of Synechococcus spp. have been compared to those of Prochlorococcus spp. and nanoplanktonic diatoms. The efficiency factor for absorption (given for a cell), which depends on both the size and the internal pigment concentration, was on average 2 times higher for Prochlorococcus spp. and 3 times higher for nanoplank- 
tonic diatoms than for Synechococcus spp. over the visible domain (Morel et al., 1993; Stramski and Mobley, 1997). Considering than the number of cells of Synechococcus spp. was on average 6 times higher than that of Prochlorococcus spp. and $\sim 1000$ times higher than that of total diatoms during P2, we may put forward that Synechococcus spp. was the main contributor to visible absorption in the mesocosm. Finally, $a_{\mathrm{p}}(442)$ and $a_{\mathrm{p}}(676)$ showed the highest positive correlation with Synechococcus spp. abundance (Table 2; Fig. 9) with a very similar evolution during P1 and P2 (Figs. 4d, 6d, e).

The absorption of CDOM also presented the highest (positive) coupling with Synechococcus spp. abundance and BP (Figs. 3f, 4d, 6a, b; 9; Table 2), thereby suggesting CDOM was produced by heterotrophic bacteria from their assimilation of labile organic compounds released by Synechococcus spp. Indeed, the latter has been shown to release DOM (Bronk, 1999; Becker et al., 2014) that may be directly used to support heterotrophic activity (Nagata, 2000; Lefort and Gasol, 2014). These (non-coloured) labile organic substrates issued from Synechococcus spp. would be converted into chromophoric, more refractory compounds by heterotrophic bacteria (Nelson et al., 1998; Rochelle-Newall and Fisher, 2002; Nelson and Siegel, 2013). Currently, the coupling between phytoplankton and heterotrophic bacteria seems to be recognized as a major pathway for the formation of CDOM in the ocean (Rochelle-Newall and Fisher, 2002; Nelson and Siegel, 2013; Organelli et al., 2014). Interestingly, Biers et al. (2007) highlighted the role of DON, specifically amino sugars and aromatic amino acids, in the microbial production of CDOM and FDOM while Bronk et al. (1999) reported the production of DON by Synechococcus spp. Consequently, the works by Biers et al. (2007) and Bronk et al. (1999) support the assumption of the CDOM production by heterotrophic bacteria consecutive to their utilization of labile DOM (that would be in part in the form of DON) released by Synechococcus spp. cyanobacteria. CDOM could be also produced directly from Synechococcus spp., as mentioned by Romera-Castillo et al. (2011). Also, we cannot exclude the participation of other primary producers, such as diatoms, to the CDOM production through a direct release of coloured material (Romera-Castillo et al., 2010; Chari et al., 2013) or through the bacterial re-working. For example, from culture experiments, Chari et al. (2013) reported the production of CDOM by Cylindrotheca closterium, one of the most important diatom species in the mesocosm. Regarding the respective abundances of Synechococcus spp. and diatoms and their evolution all over the experiment, it seems, however, that Synechococcus spp. was a greater contributor to CDOM than diatoms. Consequently, even though it seems difficult here to discriminate the respective contributions of cyanobacterial primary producers (Synechococcus spp.) and heterotrophic bacteria in the production of CDOM, unambiguously the coupling between both plays a key role in the absorption of particulate and dissolved chromophoric material in the mesocosm.

\subsubsection{Link between absorption, Synechococcus spp. and $\mathrm{N}_{2}$ fixation}

During the first part of the experiment (P1), the diazotrophic community was dominated by diatoms-diazotrophs associations (DDAs) (Fig. 4a), more specifically heterocyst-forming Richelia associated with Rhizosolenia (Turk-Kubo et al., 2015). The decrease observed in phytoplankton biomass (including diatoms, Synechococcus spp., Prochlorococcus spp., pico- and nano-eukaryotes), $\mathrm{BP}$ and organic $\mathrm{C} / \mathrm{N}$ pools from day 4 to day 9-11 (Figs. 3a-d, f; 4c-g) was attributable to a $\mathrm{N}$ limitation. In fact, during the first days, phytoplankton would have consumed the small stock of nitrates remaining in the water column without new inputs. In addition, DDAs would not have been a significant source of $\mathrm{N}$ for its surrounding environment because Richelia would have given the major part of the $\mathrm{N}$ that they had fixed to their host diatoms (Berthelot et al., 2015). This decrease in Synechococcus spp. and $\mathrm{BP}$ led to the decrease in CDOM and particulate matter absorption (Fig. 6a, b, d, e). During P1, the total amount of $\mathrm{N}$ issued from the $\mathrm{N}_{2}$ fixation was equivalent to the total amount of PON exported, suggesting there is a rapid and possibly direct export of the recently fixed $\mathrm{N}_{2}$ by DDAs (Berthelot et al., 2015). In the second part of the experiment (P2), unicellular cyanobacteria Group C (UCYN-C) became the dominant diazotrophs (Fig. 4b). The UCYN-C bloom was induced by the phosphate fertilization and increasing temperatures (Turk-Kubo et al., 2015). Consequently, $\mathrm{N}_{2}$ fixation rates were higher during P2 than during P1 (Berthelot et al., 2015). From these authors, the N released by UCYN$\mathrm{C}$ (in the form of DON and/or $\mathrm{NH}_{4}^{+}$) allowed for supporting non-diazotrophic cyanobacterial and heterotrophic bacterial growths. This would have in turn stimulated the production of dissolved and particulate chromophoric materials (increase in TChl $a$, PON, TOC, BP, Synechococcus spp., $a_{\mathrm{g}}(370,442)$ and $a_{\mathrm{p}}(442,676)$ from day $9-11$ to day $21-23$; Figs. 3a, c, d, f; 4d; 6a, b, d, e). The enhancement of Synechococcus spp. via the release of $\mathrm{N}$ by diazotrophs has been already underscored by Agawin et al. (2007). This N release could also explain the strong increase in diatoms (mainly Cylindrotheca closterium) at day 15 (Fig. 4c). In P2, both $\mathrm{N}_{2}$ fixation and DON consumption were significant $\mathrm{N}$ sources for primary production and might explain the PON production (Berthelot et al., 2015). It is worth noting that a perfect temporal synchronization occurred between the variations of Synechococcus spp./BP and the variations of CDOM and particulate matter absorption. This implies rapidity in the production mechanisms of the chromophoric material inside the mesocosm. The variations of $S_{\mathrm{g}}$ (Fig. 6c) (no correlation with $a_{\mathrm{g}}(370,442)$; Table 2$)$ suggested that CDOM absorption was not only influenced by production processes but was also probably affected by photo- and microbial-degradation 
processes. It is very likely that these degradation processes were not intense enough to counterbalance the production of CDOM by the couple Synechococcus spp./heterotrophic bacteria.

\subsubsection{Absorption budget}

Also, the contribution of CDOM $\left(a_{\mathrm{g}}\right)$ to the total absorption $\left(a_{\mathrm{g}+\mathrm{p}}\right)$ remained high in the UV domain $(370 \mathrm{~nm})$, ranging from 72 to $96 \%$, while it decreased from the beginning (50$66 \%)$ to the end of the experiment $(40-48 \%)$ in the visible domain $(442 \mathrm{~nm})$. These percentages in the UV and visible domains are in line with those reported in the literature for the open ocean (Siegel et al., 2002, 2005; Tedetti et al., 2010), the higher contribution of particulate material in the absorption budget at $442 \mathrm{~nm}$ during the second part of the experiment being explained by the bloom of cyanobacterial primary producers (Synechococcus spp.).

\subsubsection{FDOM decoupling}

FDOM did neither follow the evolution of CDOM nor the evolution of heterotrophic bacteria and Synechococcus spp. (Fig. 8; Table 2). The evolution of tyrosine-like fluorophore, whose fluorescence intensity was higher in P1 than in P2 (Table 1), tended to be close to that of DDAs (Figs. 4a, 8c; Table 2). Therefore, we may hypothesize a role of these diatoms-diazotrophs associations in the production of the tyrosine-like material. The tyrosine-like fluorophore released by phytoplankton could then be consumed by heterotrophic bacteria as labile substrates. UVC humic-like fluorophore displayed an evolution close to that of tryptophan material with two important decreases at days 7-8 and 15 . This observation supports the hypothesis by Stedmon and Cory (2014) of an association between humic substances and tryptophan fluorophore in seawater. This revealed that the humic-like component was also subjected to production/degradation processes in the mesocosm that cannot be precisely identified here. The fact that CDOM which absorbs light at $370 \mathrm{~nm}$ was not fluorescent (no fluorophores with Ex peak at $370 \mathrm{~nm}$ ) strengthened the assumption that $a_{\mathrm{g}}(370)$ and the three fluorophores represented independent chromophoric materials that were driven by different processes. Also, these fluorophores could be not major components of the CDOM. Consequently, they would absorb but not strongly enough to significantly affect the CDOM variability. Tryptophan- and tyrosine-like fluorophores belonged to the DON pool. Nonetheless, they showed different patterns in the mesocosm: while DON decreased during P2 (both the DON consumption and the $\mathrm{N}_{2}$ fixation supported the PON production during P2; Berthelot et al., 2015), the two fluorophores tended to increase. This suggested that tryptophanand tyrosine-like materials were probably not involved in the PON production.

\section{Conclusions}

Studies dealing with the CDOM dynamics in the frame of mesocosm experiments remain limited so far and have been conducted merely in coastal-temperate or polar ecosystems (Rochelle-Newall et al., 1999, 2004; Pavlov et al., 2014). This work highlights the spectral characteristics and the variability of dissolved and particulate chromophoric materials throughout a 23-day mesocosm experiment in a tropical, oligotrophic LNLC ecosystem in which $\mathrm{N}_{2}$ fixers and picophytoplankton play an essential role. Although CDOM did not display any specific shoulders in its absorption spectra, those of particulate chromophoric material were dominated by Chl $a$ fingerprint with small signatures of carotenoids, phycourobilin and phycoerythrobilin, which could be related to Synechococcus spp., the most abundant cyanobacterial group in the mesocosm. The dynamics of CDOM and particulate matter were strongly coupled with those of Synechococcus spp. and bacterial production. Indeed, in the second part of the experiment, the $\mathrm{N}$ released in the surrounding environment, very likely by UCYN-C diazotrophs, allowed for supporting cyanobacterial and heterotrophic bacterial growths and subsequently stimulating the production of dissolved and particulate chromophoric materials. The increase in phytoplankton biomass during the second part of the experiment led to a higher contribution of particulate material in the absorption budget at $442 \mathrm{~nm}$. FDOM, composed by (N-containing) protein-like fluorophores and UVC humiclike (photoproduct) fluorophore, did not follow the evolution of CDOM and particulate matter, and was thus subjected to different production/degradation processes in the mesocosm. Finally, this study strongly supports the idea of an indirect link between the dynamics of the $\mathrm{N}_{2}$ fixation and that of chromophoric material in the south-west Pacific.

Acknowledgements. Funding for this research was provided by the Agence Nationale de la Recherche (ANR starting grant VAHINE ANR-13-JS06-0002), INSU-LEFE-CYBER program, GOPS, IRD and M.I.O. The authors thank the captain and crew of the R/V Alis. We acknowledge the SEOH divers service from the IRD research centre of Noumea (E. Folcher, B. Bourgeois and A. Renaud) and from the Observatoire Océanologique de Villefranche-sur-mer (OOV, J. M. Grisoni) as well as the technical service of the IRD research centre of Noumea for their helpful technical support. C. Guieu, F. Louis and J. M. Grisoni from OOV are warmly thanked for the mesocosms design and their useful advice for deployment. We also thank A. Desnues, B. Charrière, H. Berthelot, J. Héliou and T. Moutin for their help and assistance in the sampling and analyses. S. Bonnet, PI of the VAHINE project, and J. Neveux are greatly acknowledged for their constructive comments and discussions on the early versions of the manuscript. Two anonymous Reviewers are acknowledged for their relevant comments and corrections, which contributed to improve the quality of this manuscript.

Edited by: S. Bonnet 


\section{References}

Agawin, N. S. R., Rabouille, S., Veldhuis, M. J. W., Servatius, L., Hol, S., van Overzee, H. M. J., and Huisman, J.: Competition and facilitation between unicellular nitrogen-fixing cyanobacteria and non-nitrogen-fixing phytoplankton species, Limnol. Oceanogr., 52, 2233-2248, 2007.

Aminot, A. and Kérouel, R.: Dosage automatique des nutriments dans les eaux marines: méthodes en flux continu, Ed. Ifremer, Méthodes d'analyse en milieu marin, 188 pp., 2007.

Andrew, A. A., Del Vecchio, R., Subramaniam, A., and Blough, N. V.: Chromophoric dissolved organic matter (CDOM) in the Equatorial Atlantic Ocean: Optical properties and their relation to CDOM structure and source, Mar. Chem., 148, 33-43, 2013.

Antoine, D., Babin, M., Berthon, J. F., Bricaud, A., Gentili, B., Loisel, H., Maritorena, S., and Stramski, D.: Shedding Light on the Sea: André Morel's Legacy to Optical Oceanography, Ann. Rev. Mar. Sci., 6, 15.1-15.21, 2014.

Babin, M., Stramski, D., Ferrari, G. M., Claustre, H., Bricaud, A., Obolensky, G., and Hoepffner, N.: Variations in the light absorption coefficients of phytoplankton, nonalgal particles, and dissolved organic matter in coastal waters around Europe, J. Geophys. Res., 108, 3211, doi:10.1029/2001JC000882, 2003.

Balcarczyk, K. L., Jones Jr., J. B., Jaffe, R., and Maie, N.: Stream dissolved organic matter bioavailability and composition in watersheds underlain with discontinuous permafrost, Biogeochemistry, 94, 255-270, 2009.

Becker, J. W., Berube, P. M. Follett, C. L., Waterbury, J. B., Chisholm, S. W., Delong, E. F., and Repeta, D. J.: Closely related phytoplankton species produce similar suites of dissolved organic matter, Front. Microbiol., 5, 111, doi:10.3389/fmicb.2014.00111, 2014.

Berthelot, H., Moutin, T., L'Helguen, S., Leblanc, K., Hélias, S., Grosso, O., Leblond, N., Charrière, B., and Bonnet, S.: Dinitrogen fixation and dissolved organic nitrogen fueled primary production and particulate export during the VAHINE mesocosm experiment (New Caledonia lagoon), Biogeosciences, 12, 40994112, doi:10.5194/bg-12-4099-2015, 2015.

Bidigare, R., Schofield, O., and Prezelin, B.: Influence of zeaxanthin on quantum yield of photosynthesis of Synechococcus clone WH 7803 (CD2), Mar. Ecol.-Prog. Ser., 56, 177-188, 1989.

Biegala, I. C. and Raimbault, P.: High abundance of diazotrophic picocyanobacteria $(<3 \mu \mathrm{m})$ in a Southwest Pacific coral lagoon, Aquat. Microb. Ecol., 51, 45-53, 2008.

Biers, E. J., Zepp, R. G., and Moran, M. A.: The role of nitrogen in chromophoric and fluorescent dissolved organic matter formation, Mar. Chem., 103, 46-60, 2007.

Blough, N. V. and Del Vecchio, R.: Chromophoric DOM in the coastal environment, in: Biogeochemistry of Marine Dissolved Organic Matter, edited by: Hansel, D. A. and Carlson, C. A., Academic Press, San Diego, California, 509-546, 2002.

Bonnet, S., Moutin, T., Rodier, M., Grisoni, J.-M., Louis, F., Folcher, E., Bourgeois, B., Boré, J.-M., and Renaud, A.: Introduction to the project VAHINE: VAriability of vertical and tropHIc transfer of diazotroph derived $\mathrm{N}$ in the south wEst Pacific, Biogeosciences, 13, 2803-2814, doi:10.5194/bg-13-28032016, 2016.

Bracchini, L., Tognazzi, A., Dattilo, A. M., Decembrini, F., Rossi, C., and Loiselle, S. A.: Sensitivity analysis of CDOM spectral slope in artificial and natural samples: an application in the central eastern Mediterranean Basin, Aquat. Sci., 72, 485-498, 2010.

Bricaud, A., Claustre, H., Ras, J., and Oubelkheir, K.: Natural variability of phytoplanktonic absorption in oceanic waters: Influence of the size structure of algal populations, J. Geophys. Res., 109, C11010, doi:10.1029/2004JC002419, 2004.

Bricaud, A., Babin, M., Claustre, H., Ras, J., and Tièche, F.: Light absorption properties and absorption budget of Southeast Pacific waters, J. Geophys. Res., 115, C08009, doi:10.1029/2009JC005517, 2010.

Bronk, D. A.: Rates of $\mathrm{NH}_{4}^{+}$uptake, intracellular transformation, and dissolved organic nitrogen release in two clones of marine Synechococcus spp., J. Plankton Res., 21, 1337-1353, 1999.

Carreto, J. J.: A new keto-carotenoid from the dino-flagellate Protopendinium depressurn (Bayley) Balech, 1974, J. Plankton Res., 7, 421-423, 1985.

Chari, N. V. H. K., Keerthi, S., Sarma, N. S., Rao Pandi, S., Chiranjeevulu, G., Kiran, R., and Koduru, U.: Fluorescence and absorption characteristics of dissolved organic matter excreted by phytoplankton species of western Bay of Bengal under axenic laboratory condition, J. Exp. Mar. Biol. Ecol., 445, 148-155, 2013.

Coble, P. G.: Characterization of marine and terrestrial DOM in seawater using excitation emission matrix spectroscopy, Mar. Chem., 51, 325-346, 1996.

Coble, P. G.: Marine optical biogeochemistry - the chemistry of ocean color, Chem. Rev., 107, 402-418, 2007.

Davis, J. and Benner, R: Quantitative estimates of labile and semilabile dissolved organic carbon in the western Arctic Ocean: A molecular approach, Limnol. Oceanogr., 52, 2434-2444, 2007.

Del Vecchio, R. and Blough, N. V.: Photobleaching of chromophoric dissolved organic matter in natural waters: Kinetics and modelling, Mar. Chem. 78, 231-253, 2002.

Dupouy, C., Petit, M., and Dandonneau, Y.: Satellite detected cyanobacteria bloom in the southwestern tropical Pacific. Implication for nitrogen fixation, Int. J. Remote Sens., 8, 389-396, 1988.

Dupouy, C., Neveux, J., and André, J. M.: Spectral absorption coefficient of photosynthetically active pigments in the equatorial Pacific $\left(165^{\circ} \mathrm{E}-150^{\circ} \mathrm{W}\right)$, Deep-Sea Res. Pt. II, 44, 1881-1906, 1997.

Dupouy, C., Loisel, H., Neveux, J., Brown, S. L., Moulin, C., Blanchot, J., Le Bouteiller, A., and Landry, M. R.: Microbial absorption and backscattering coefficients from in situ and POLDER satellite data during an El Nino-Southern Oscillation cold phase in the equatorial Pacific $\left(180^{\circ}\right)$, J. Geophys. Res., 108, 8138, doi:10.1029/2001JC001298, 2003.

Dupouy, C., Neveux, J., Dirberg, G., Röttgers, R., Tenório, M. M. B., and Ouillon, S.: Bio-optical properties of the marine cyanobacteria Trichodesmium spp, J. Appl. Remote Sens., 2, 117, 2008.

Dupouy, C., Frouin, R., Röttgers, R., Neveux, J., Gallois, F., Panché, J. Y., Gérard, P., Fontana, C., Pinazo, C., Ouillon, S., and Minghelli-Roman, A.: Ocean color response to an episode of heavy rainfall in the lagoon of New Caledonia, Proc. SPIE, 7459, Ocean Remote Sensing: Methods and Applications, 7459, 74590G, doi:10.1117/12.829251, 2009.

Dupouy, C., Röttgers, R., Tedetti, M., Martias, C., Murakami, H., Doxaran, D., Lantoine, F., Rodier, M., Favareto, L., Kampel, M., Goutx, M., and Frouin, R.: Influence of CDOM and Particle 
Composition on Ocean Color of the Eastern New Caledonia Lagoon during the CALIOPE Cruises, Proc. of SPIE, 9261, Ocean Remote Sensing and Monitoring from Space, 92610M, 2014.

Fellman, J. B., Hood, E., and Spencer, R. G. M.: Fluorescence spectroscopy opens new windows into dissolved organic matter dynamics in freshwater ecosystems: A review, Limnol. Oceanogr., 55, 2452-2462, 2010.

Foster, R. A., Subramaniam, A., and Zehr, J. P.: Distribution and activity of diazotrophs in the Eastern Equatorial Atlantic, Environ. Microbiol., 11, 741-750, 2009.

Fuchs, R., Dupouy, C., Douillet, P., Caillaud, M., Mangin, A., and Pinazo, C.: Modelling the impact of a La Niña event on a South West Pacific Lagoon, Mar. Pollut. Bull., 64, 1596-15613, 2012.

Grenz, C., Le Borgne, R., Fichez, R., and Torréton, J. P.: Tropical lagoon multidisciplinary investigations: An overview of the PNEC New Caledonia pilot site, Mar. Pollut. Bull., 61, 267-268, 2010.

Helms, J. R., Stubbins, A., Ritchie, J. D., Minor, E. C., Kieber, D. J., and Mopper, K.: Absorption spectral slopes and slope ratios as indicators of molecular weight, source and photobleaching of chromophoric dissolved organic matter, Limnol. Oceanogr., 53, 955-969, 2008.

Hernes, P. J. and Benner, R.: Terrigenous organic matter sources and reactivity in the North Atlantic Ocean and a comparison to the Arctic and Pacific oceans, Mar. Chem., 100, 66-79, 2006.

Ishii, S. K. L. and Boyer, T. H.: Behavior of Reoccurring PARAFAC Components in Fluorescent Dissolved Organic Matter in Natural and Engineered Systems: A Critical Review, Environ. Sci. Technol., 46, 2006-2017, 2012.

Kirchman, D. L., K'nees, E., and Hodson, R.: Leucine incorporation and its potential as a measure of protein synthesis by bacteria in natural waters, Appl. Environ. Microb., 49, 599-607, 1985.

Kowalczuk, P., Durako, M. J., Young, H., Kahn, A. E., Cooper, W. J., and Gonsior, M.: Characterization of dissolved organic matter fluorescence in the South Atlantic Bight with use of PARAFACmodel: interannual variability, Mar. Chem., 113, 182-196, 2009.

Kowalczuk, P., Tilstone, G. H., Zabłocka, M., Röttgers, R., and Thomas, R.: Composition of dissolved organic matter along an Atlantic Meridional Transect from fluorescence spectroscopy and Parallel Factor Analysis, Mar. Chem., 157, 170-184, 2013.

Lantoine, F. and Neveux, J.: Spatial and seasonal variations in abundance and spectral characteristics of phycoerythrins in the tropical northeastern Atlantic Ocean, Deep-Sea Res. Pt. I, 44, 223 246, 1997.

Le Bouteiller, A., Blanchot, J., and Rodier, M.: Size distribution patterns of phytoplankton in the western Pacific: towards a generalization for the tropical open ocean, Deep-Sea Res., 39, 805-823, 1992.

Lefort, T. and Gasol, J. M.: Short-time scale coupling of picoplankton community structure and single-cell heterotrophic activity in winter in coastal NW Mediterranean Sea waters, J. Plankton Res., 36, 243-258, 2014.

Lohrenz, S. E., Weidemann, A. D., and Tuel, M.: Phytoplankton spectral absorption as influenced by community size structure and pigment composition, J. Plankton Res., 25, 35-61, 2003.

Lønborg, C., Yokokawa, T., Herndl, G. J., and Álvarez-Salgado, X. A.: Production and degradation of fluorescent dissolved organic matter in surface waters of the eastern north Atlantic ocean, Deep-Sea Res. Pt. I, 96, 28-37, 2015.
Lutz, V. A., Sathyendranath, S., and Head, E. J. H.: Absorption coefficient of phytoplankton: Regional variations in the North Atlantic, Mar. Ecol.-Prog. Ser., 135, 197-213, 1996.

Lutz, V. A., Sathyendranath, S., Head, E., and Li, W. K. W: Changes in the in vivo absorption and fluorescence excitation spectra with growth irradiance in three species of phytoplankton, J. Plankton Res., 23, 555-569, 2001.

Marie, D., Partensky, F., Vaulot, D., and Brussaard, C. P. D.: Enumeration of phytoplankton, bacteria, and viruses in marine samples, in: , Current Protocols in Cytometry, edited by: Robinson, J. P., Darzynkiewicz, Z., Dean, P. N., Orfao, A., Rabinovitch, P. S., Stewart, C. C., Tanke, H. J., and Wheeless, L. L., John Wiley \& Sons Inc., New York, 11.11.1-11.11.15, 1999.

Masotti, I., Ruiz Pino, D., and Le Bouteiller, A.: Photosynthetic characteristics of Trichodesmium in the southwest Pacific Ocean: importance and significance, Mar. Ecol.-Prog. Ser., 338, 47-59, 2007.

Matsuoka, A., Babin, M., Doxaran, D., Hooker, S. B., Mitchell, B. G., Bélanger, S., and Bricaud, A.: A synthesis of light absorption properties of the Arctic Ocean: application to semianalytical estimates of dissolved organic carbon concentrations from space, Biogeosciences, 11, 3131-3147, doi:10.5194/bg-11-3131-2014, 2014.

Morel, A.: Consequences of a Synechococcus bloom upon the optical properties of oceanic (case 1) waters, Limnol. Oceanogr., 42 , 1746-1754, 1997.

Morel, A. and Prieur, L.: Analysis of variations in ocean color, Limnol. Oceanogr., 22, 709-722, 1977.

Morel, A., Ahn, Y. H., Partensky, F., Vaulot, D., and Claustre, H.: Prochlorococcus and Synechococcus - A comparative study of their optical properties in relation to their size and pigmentation, J. Mar. Res., 51, 617-649, 1993.

Morel, A., Claustre, H., and Gentili, B.: The most oligotrophic subtropical zones of the global ocean: similarities and differences in terms of chlorophyll and yellow substance, Biogeosciences, 7, 3139-3151, doi:10.5194/bg-7-3139-2010, 2010.

Murphy, K. R., Stedmon, C. A., Waite, T. D., and Ruiz, G. M.: Distinguishing between terrestrial and autochthonous organic matter sources in marine environments using fluorescence spectroscopy, Mar. Chem., 108, 40-58, 2008.

Nagata, T.: Production mechanims of dissolved organic matter, in: Microbial Ecology of the Oceans, edited by: Kirchman, D. L., Wiley-Liss, New York, 121-152, 2000.

Nelson, N. B. and Siegel, D. A.: The Global Distribution and Dynamics of Chromophoric Dissolved Organic Matter, Annu. Rev. Mar. Sci., 5, 447-476, 2013.

Nelson, N. B., Siegel, D. A., and Michaels, A. F.: Seasonal dynamics of colored dissolved material in the Sargasso Sea, Deep-Sea Res. Pt. I, 45, 931-957, 1998.

Nelson, N. B., Siegel, D. A., Carlson, C. A., and Swan, C. M.: Tracing global biogeochemical cycles and meridional overturning circulation using chromophoric dissolved organic matter, Geophys. Res. Lett. 37, L03610, doi:10.1029/2009GL042325, 2010.

Neveux, J., Lantoine, F., Vaulot, D., Marie, D., and Blanchot, J.: Phycoerythrins in the southern tropical and equatorial Pacific Ocean: evidence for new cyanobacterial types, J. Geophys. Res., 104, 3311-3321, 1999.

Neveux, J., Tenório, M. M. B., Jacquet, S., Torréton, J.-P., Douillet, P., Ouillon, S., and Dupouy, C.: Chlorophylls and Phycoery- 
thrins as Markers of Environmental Forcings Including Cyclone Erica Effect (March 2003) on Phytoplankton in the Southwest Lagoon of New Caledonia and Oceanic Adjacent Area, Intern. J. Oceanogr., 2009, 232513, doi:10.1155/2009/232513, 2009.

Nieto-Cid, M., Álvarez-Salgado, X. A., and Pérez, F. F.: Microbial and photochemical reactivity of fluorescent dissolved organic matter in a coastal upwelling system, Limnol. Oceanogr., 51, 1391-1400, 2006.

Organelli, E., Bricaud, A., Antoine, D., and Matsuoka, A.: Seasonal dynamics of light absorption by chromophoric dissolved organic matter (CDOM) in the NW Mediterranean Sea (BOUSSOLE site), Deep-Sea Res. Pt. I, 91, 72-85, 2014.

Ortega-Retuerta, E., Frazer, T. K., Duarte, C. M., Ruiz-Halpern, S., Tovar-Sanchez, A., Arrieta, J. M., and Reche, I.: Biogeneration of chromophoric dissolved organic matter by bacteria and krill in the Southern Ocean, Limnol. Oceanogr., 54, 1941-1950, 2009.

Ouillon, S., Douillet, P., Lefebvre, J. P., Le Gendre, R., Jouon, A., Bonneton, P., Fernandez, J. M., Chevillon, C., Magand, O., Lefèvre, J., Le Hir, P., Laganier, R., Dumas, F., Marchesiello, P., Bel Madani, A., Andréfouët, S., Panché, J. Y., and Fichez, R.: Circulation and suspended sediment transport in a coral reef lagoon: The south-west lagoon of New Caledonia, Mar. Pollut. Bull., 61, 269-296, 2010.

Para, J., Coble, P. G., Charrière, B., Tedetti, M., Fontana, C., and Sempéré, R.: Fluorescence and absorption properties of chromophoric dissolved organic matter (CDOM) in coastal surface waters of the northwestern Mediterranean Sea, influence of the Rhône River, Biogeosciences, 7, 4083-4103, doi:10.5194/bg-74083-2010, 2010.

Pavlov, A. K., Silyakova, A., Granskog, M. A., Bellerby, R. G. J., Engel, A., Schulz, K. G., and Brussaard C. P. D.: Marine CDOM accumulation during a coastal Arctic mesocosm experiment: No response to elevated $\mathrm{pCO}_{2}$ levels, J. Geophys. Res.-Biogeo., 119, 1216-1230, doi:10.1002/2013JG002587, 2014.

Pujo-Pay, M. and Raimbault, P.: Improvement of the Wet-Oxidation Procedure for Simultaneous Determination of Particulate Organic Nitrogen and Phosphorus Collected on Filters, Mar. Ecol.Prog. Ser., 105, 203-207, 1994.

Rochelle-Newall, E. J. and Fisher, T. R.: Production of chromophoric dissolved organic matter fluorescence in marine and estuarine environments: an investigation into the role of phytoplankton, Mar. Chem., 77, 7-21, 2002.

Rochelle-Newall, E. J., Fisher, T. R., Fan, C., and Glibert, P. M.: Dynamics of chromophoric dissolved organic matter and dissolved organic carbon in experimental mesocosms, Int. J. Remote Sens., 20, 627-641, 1999.

Rochelle-Newall, E., Delille, B., Frankignoulle, M., Gattuso, J. P., Jacquet, S., Riebesell, U., Terbrüggen A., and Zondervan, I.: Chromophoric dissolved organic matter in experimental mesocosms maintained under different pCO2 levels, Mar. Ecol.-Prog. Ser., 272, 25-31, 2004.

Rodier, M. and Le Borgne, R.: Population and trophic dynamics of Trichodesmium thiebautii in the SE lagoon of New Caledonia. Comparison with T. erythraeum in the SW lagoon, Mar. Pollut. Bull., 61, 349-359, 2010.

Romera-Castillo, C., Sarmento, H., Álvarez-Salgado, X. A., Gasol, J. M., and Marrasé, C.: Production of chromophoric dissolved organic matter by marine phytoplankton, Limnol. Oceanogr., 55, 446-454, 2010.
Romera-Castillo, C., Sarmento, H., Álvarez-Salgado, X. A., Gasol, J. M., and Marrasé, C.: Net Production and Consumption of Fluorescent Colored Dissolved Organic Matter by Natural Bacterial Assemblages Growing on Marine Phytoplankton Exudates, Appl. Environ. Microbiol., 77, 7490-7498, 2011.

Röttgers, R. and Doerffer, R.: Measurements of optical absorption by chromophoric dissolved organic matter using a point-source integrating-cavity absorption meter, Limnol. Oceanogr.-Meth., 5, 126-135, 2007.

Röttgers, R. and Koch, B. P.: Spectroscopic detection of a ubiquitous dissolved pigment degradation product in subsurface waters of the global ocean, Biogeosciences, 9, 2585-2596, doi:10.5194/bg-9-2585-2012, 2012.

Röttgers, R., Häse, C., and Doerffer, R.: Determination of the particulate absorption of microalgae using a point-source integratingcavity absorption meter: verification with a photometric technique, improvements for pigment bleaching and correction for chlorophyll fluorescence, Limnol. Oceanogr.-Meth., 5, 1-12, 2007.

Röttgers, R., Dupouy, C., Taylor, B. B., Bracher, A., and Wozniak, S. B.: Mass-specific light absorption coefficients of natural aquatic particles in the near-infrared spectral region, Limnol. Oceanogr., 59, 1449-1460, 2014.

Sempéré, R., Para, J., Tedetti, M., Charrière, B., and Mallet, M.: Variability of solar radiation and CDOM in surface coastal waters of the Northwestern Mediterranean Sea, Photochem. Photobiol., 91, 851-861, 2015.

Siegel, D. A., Maritorena, S., Nelson, N. B., Hansell, D. A., and Lorenzi-Kayser, M.: Global distribution and dynamics of colored dissolved and detrital organic materials, J. Geophys. Res., 107, 3228, doi:10.1029/2001JC000965, 2002.

Siegel, D. A., Maritorena, S., Nelson, N. B., and Behrenfeld, M. J.: Independence and interdependencies of global ocean color properties; Reassessing the bio-optical assumption, J. Geophys. Res., 110, C07011, doi:10.1029/2004JC002527, 2005.

Smith, D. C. and Azam, F.: A simple, economical method for measuring bacterial protein synthesis rates in sea water using $3 \mathrm{H}-$ Leucine, Mar. Microb. Food Webs, 6, 107-114, 1992.

Sohrin, R. and Sempéré, R.: Temporal variation in total organic carbon in the Northeast Atlantic in 2000-2001, J. Geophys. Res., 110, C10S90, doi:10.1029/2004JC002731, 2005.

Stedmon, C. A. and Bro, R.: Characterizing dissolved organic matter fluorescence with parallel factor analysis: a tutorial, Limnol. Oceanogr.-Meth., 6, 572-579, 2008.

Stedmon, C. A. and Cory, R. M.: Biological Origins and Fate of Fluorescent Dissolved Organic Matter in Aquatic Environments, in: Aquatic Organic Matter Fluorescence, edited by: Coble, P. G., Lead, J., Baker, A., Reynolds, D. M., and Spencer, R. G. M., Cambridge University Press, New York, 278-299, 2014.

Stedmon, C. A., Markager, S., and Bro, R.: Tracing dissolved organic matter in aquatic environments using a new approach to fluorescence spectroscopy, Mar. Chem., 82, 239-254, 2003.

Steinberg, D. K., Nelson, N., Carlson, C. A., and Prusak, A. C.: Production of chromophoric dissolved organic matter (CDOM) in the open ocean by zooplankton and the colonial cyanobacterium Trichodesmium spp., Mar. Ecol.-Prog. Ser., 267, 45-56, 2004.

Stramski, D. and Mobley, C. D.: Effects of microbial particles on oceanic optics: A database of single-particle optical properties, Limnol. Oceanogr., 42, 538-549, 1997. 
Stuart, V., Sathyendranath, S., Platt, T., Maass, H., and Irwin, B. D.: Pigment and species composition of natural phytoplankton populations: Effect on the absorption spectra, J. Plankton Res., 20, 187-217, 1998.

Subramaniam, A., Carpenter, E. J., Karentz, D., and Falkowski, P. G.: Bio-optical properties of the marine diazotrophic cyanobacteria Trichodesmium spp. I. Absorption and photosynthetic action spectra, Limnol. Oceanogr., 44, 608-617, 1999.

Swan, C. M., Siegel, D. A., Nelson, N. B., Carlson, C. A., and Nasir, E.: Biogeochemical and hydrographic controls on chromophoric dissolved organic matter distribution in the Pacific Ocean, DeepSea Res. Pt. I, 56, 2175-2192, 2009.

Swan, C. M., Siegel, D. A., Nelson, N. B., and Kostadinov, T. S.: The effect of surface irradiance on the absorption spectrum of chromophoric dissolved organic matter in the global ocean, Deep-Sea Res. Pt. I, 63, 52-64, 2012.

Tedetti, M., Sempéré, R., Vasilkov, A., Charrière, B., Nérini, D., Miller, W., Kawamura, K., and Raimbault, P.: High penetration of ultraviolet radiation in the south east Pacific waters, Geophys. Res. Lett., 34, L12610, doi:10.1029/2007GL029823, 2007.

Tedetti, M., Charrière, B., Bricaud, A., Para, J., Raimbault, P., and Sempéré, R.: Distribution of normalized waterleaving radiances at UV and visible wave bands in relation with chlorophyll $a$ and colored detrital matter content in the southeast Pacific, J. Geophys. Res., 115, C02010, doi:10.1029/2009JC005289, 2010.

Tedetti, M., Longhitano, R., Garcia, N., Guigue, C., Ferretto, N., and Goutx, M.: Fluorescence properties of dissolved organic matter in coastal Mediterranean waters influenced by a municipal sewage effluent (Bay of Marseilles, France), Environ. Chem., 9, 438-449, 2012.

Tilstone, G. H., Peters, S. W. M., van derWoerd, H. J., Eleveld, M. A., Ruddick, K., Schönfeld, W., Krasemann, H., MartinezVicente, V., Blondeau-Patissier, D., Röttgers, R., Sørensen, K., Jørgenseng, P. V., and Shutler, J. D.: Variability in specificabsorption properties and their use in a semianalytical ocean colour algorithm for MERIS in north sea andwestern English channel coastal waters, Remote Sens. Environ., 118, 320-338, 2012 .
Turk-Kubo, K. A., Frank, I. E., Hogan, M. E., Desnues, A., Bonnet, S., and Zehr, J. P.: Diazotroph community succession during the VAHINE mesocosm experiment (New Caledonia lagoon), Biogeosciences, 12, 7435-7452, doi:10.5194/bg-12-7435-2015, 2015.

Twardowski, M. S., Boss, E., Sullivan, J. M., and Donaghay, P. L.: Modeling the spectral shape of absorption by chromophoric dissolved organic matter, Mar. Chem., 89, 69-88, 2004.

Vernet, M. and Whitehead, K.: Release of ultraviolet-absorbing compounds by the red-tide dinoflagellate Lingulodinium polyedra, Mar. Biol., 127, 35-44, 1996.

Whitehead, K. and Vernet, M.: Influence of mycosporine-like amino acids (MAAs) on UV absorption by particulate and dissolved organic matter in La Jolla Bay, Limnol. Oceanogr., 45, 1788-1796, 2000.

Wozniak, B., Dera, J., Ficek, D., Machrowski, R., Kaczmarek, S., Ostrowska, M., and Koblentz-Mischke, O. I.: Modelling the influence of acclimation on the absorption properties of marine phytoplankton, Oceanologia, 41, 187-210, 1999.

Wyman, M.: An in vivo method for the estimation of phycoerythrin concentrations in marine cyanobacteria (Synechococcus spp.), Limnol. Oceanogr., 37, 1300-1306, 1992.

Xing, X., Claustre, H., Wang, H., Poteau, A., and D'Ortenzio, F.: Seasonal dynamics in colored dissolved organic matter in the Mediterranean Sea: patterns and drivers, Deep-Sea Res. Pt. I, 83 , 93-101, 2014.

Yamashita, Y. and Tanoue, E.: In situ production of chromophoric dissolved organic matter in coastal environments, Geophys. Res. Lett., 31, 1-4, doi:10.1029/2004GL019734, 2004.

Yamashita, Y., Jaffe, R., Maie, N., and Tanoue, E.: Assessing the dynamics of dissolved organic matter (DOM) in coastal environments by excitation emission matrix fluorescence and parallel factor analysis (EEM-PARAFAC), Limnol. Oceanogr., 53, 19001908, 2008.

Yamashita, Y., Nosaka, Y., Suzuki, K., Ogawa, H., Takahashi, K., and Saito, H.: Photobleaching as a factor controlling spectral characteristics of chromophoric dissolved organic matter in open ocean, Biogeosciences, 10, 7207-7217, doi:10.5194/bg-107207-2013, 2013. 